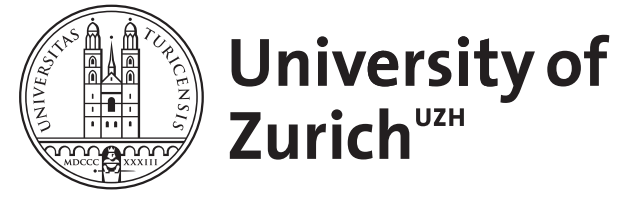

\title{
Neuroendocrine control of satiation
}

\author{
Asarian, Lori ; Bächler, Thomas
}

\begin{abstract}
Eating is a simple behavior with complex functions. The unconscious neuroendocrine process that stops eating and brings a meal to its end is called satiation. Energy homeostasis is mediated accomplished through the control of meal size via satiation. It involves neural integrations of phasic negative-feedback signals related to ingested food and tonic signals, such as those related to adipose tissue mass. Energy homeostasis is accomplished through adjustments in meal size brought about by changes in these satiation signals. The best understood meal-derived satiation signals arise from gastrointestinal nutrient sensing. Gastrointestinal hormones secreted during the meal, including cholecystokinin, glucagon-like peptide 1, and PYY, mediate most of these. Other physiological signals arise from activation of metabolic-sensing neurons, mainly in the hypothalamus and caudal brainstem. We review both classes of satiation signal and their integration in the brain, including their processing by melanocortin, neuropeptide Y/agouti-related peptide, serotonin, noradrenaline, and oxytocin neurons. Our review is not comprehensive; rather, we discuss only what we consider the best-understood mechanisms of satiation, with a special focus on normally operating physiological mechanisms.
\end{abstract}

DOI: https://doi.org/10.1515/hmbci-2014-0010

Posted at the Zurich Open Repository and Archive, University of Zurich

ZORA URL: https://doi.org/10.5167/uzh-101208

Journal Article

Accepted Version

Originally published at:

Asarian, Lori; Bächler, Thomas (2014). Neuroendocrine control of satiation. Hormone Molecular Biology and Clinical Investigation, 19(3):163-192.

DOI: https://doi.org/10.1515/hmbci-2014-0010 


\section{Title: Neuroendocrine control of satiation}

Authors: Lori Asarian ${ }^{1,2}$ and Thomas Bächler ${ }^{1}$

Affiliation: ${ }^{1}$ University of Zurich, Institute of Veterinary Physiology, Winterthurerstrasse 260, 8057, Zurich, Switzerland and ${ }^{2}$ Center of Integrative and Human Physiology (ZIHP), University of Zurich, Zurich, Switzerland

\section{Corresponding Author:}

Lori Asarian

University of Zurich

Institute of Veterinary Physiology

Winterthurerstrasse 260

8057, Zurich

Switzerland

Tel: +41446358836

Fax: +41446358932

Email: lasarian@vetphys.uzh.ch

Running title: Neuroendocrine control of satiation 


\begin{abstract}
Eating is a simple behavior with complex functions. The unconscious neuroendocrine process that stops eating and brings a meal to its end is called satiation. Energy homeostasis is mediated accomplished through the control of meal size by via satiation. It involves neural integrations of phasic negativefeedback signals related to ingested food and to tonic signals, such as those related to adipose-tissue mass. Energy homeostasis is accomplished through adjustments in meal size brought about by changes in these satiation signals. The best understood meal-derived satiation signals arise from gastrointestinal (GI) nutrient-sensing. GI hormones secreted during the meal, including CCK, GLP-1 and PYY, mediate most of these. Other physiological signals arise from activation of metabolic-sensing neurons, mainly in the hypothalamus and caudal brainstem. We review both classes of satiation signal and their integration in the brain, including their processing by melanocortin, NPY/AgRP, serotonin, noradrenaline, and oxytocin neurons. Our review is not comprehensive; rather, we discuss only what we consider the best-understood mechanisms of satiation, with a special focus on normally operating physiological mechanisms.
\end{abstract}

Keywords: eating, gastrointestinal, brain, nutrient sensing, gut peptides 


\section{Abbreviations:}

$5 \mathrm{HT}=$ serotonin; $\mathrm{AAV}=$ adeno-associated virus; $\mathrm{AgRP}=$ agouti related peptide; $\mathrm{CART}=$ cocaine and amphetamine receptor transcript; CCK=cholecystokinin; DPP IV=dipeptidyl peptidase IV; $\mathrm{DMN}=$ dorsomedial nucleus of the hypothalamus; DVC=dorsovagal complex; FFA=free fatty acids; GE=glucoseexcited; $\mathrm{Gl}=$ glucose inhibited; GIP=glucose inhibitory protein; GK=glucokinase; GLP-1=glucagon-like peptide 1; GPCR=G protein coupled receptors; JAK=Janus Kinase; LCFA=long-chain fatty acid; $M=$ =muscarinic; $M C=$ melanocortin; NPY=neuropeptide $Y$; NTS=nucleus tractus solitarius; OEA=oleoylethanolamine; OLETF=Otsuka Long-Evans Tokushima Fatty rat; POMC=proopiomelanocortin; SCFA $=$ small chain fatty acid. 


\section{Introduction}

Energy homeostasis refers to two processes: (a) the regulation of an adequate readily available supply of energy metabolites in the circulation and (b) the regulation of adipose tissue mass, which is the major energy store. These are among the most important biological functions of any organism. Both aspects of energy homeostasis are linked to eating. Eating normally results in the entry of sufficient energy metabolites from the intestines into the circulation except during intense exercise and the "postabsorptive state;" i.e., early in the morning, when the stomach is entirely empty and intestinal absorption slows. Glycogenolysis and lipolysis take up the slack in such situations. Over the longer term, stability of the adipose-tissue mass, or "lipostasis," requires that the energetic content of food eaten be balanced with energy expended in metabolism and physical work (in adults, in whom growth can be ignored). If this energy equation is imbalanced, fat stores and body weight will drift upwards or downwards. Perhaps the most convincing evidence that adipose tissue mass is actively regulated is that experimental perturbations of adipose tissue mass lead to compensatory eating and energy expenditure responses that re-establish normality [1]. Figure 1 shows an example [2, 3].

Humans, rats and mice eat in the form of meals. Thus, study of the neuroendocrine bases of eating should, and ultimately must, target the mechanisms controlling meal size and frequency. Furthermore, the homeostatic controls of eating described above must be manifested as changes in patterns of meal frequency or meal size. Meal size is the clearly decisive parameter in rats: (a) the total amount eaten over days correlates with average meal size, but not with meal frequency [4]; (b) diluting the energy content of the diet results in immediate increases in meal size, with little change in meal frequency [5]; (c) in a cold environment rats ate larger, but less frequent, meals [6]; (d) diabetic rats that cannot metabolize glucose normally increase meal size rather than meal frequency [5, 7, 8]; (e) during lactation rats increase meal size sooner and more than meal frequency [9]; (f) the increased energetic demand brought about by female rats' avid wheel running is met by increasing meal size [10]; (g) the hyperphagia of obese Zucker rats, which have defective leptin receptor signaling is caused by increased meal size rather than meal frequency [11, 12], and chronic leptin administration increases meal size, not meal frequency $[13,14]$ and perhaps most convincing, (h) compensatory eating in rats recovering from enforced overweight or forced underweight is usually accomplished by adjusting meal size, not meal frequency [2, 3, 15-17] (Table 1). In contrast to the selective effect of energy-homeostatic challenges on meal size, rats' meal frequency seems more sensitive to the very different homeostatic challenges such as occur during illness [18-21]. Furthermore, in humans, social conditioning is normally the major controller of meal timing. For these reasons, we focus here on the mechanisms by which energy homeostasis controls meal size. 
Current understanding indicates that the contributions of meal size to the two aspects of energy homeostasis described above arise from two different classes of feedback signals. The first class, described by Smith [22] as the direct controls of meal size, consists of negative feedbacks that are generated during meals in the gastrointestinal $(\mathrm{Gl})$ tract from preabsorptive nutrient stimuli, and their primary effect is to inhibit eating and bring the meal to an end, i.e., to produce satiation. This feedback mechanism is shown schematically in the inner feedback loop in Figure 2. We discuss the Gl nutrient-sensing mechanisms mediating the direct controls of satiation in Section 2 of the review. The second class of feedbacks is comprised of circulating energy metabolites and hormones involved in energy metabolism. These arise from nutrient absorption and from organs involved in energy metabolism such as the liver, pancreas, and adipose tissue, and they act on a widely distributed set of what Levin et al. call "metabolic-sensing neurons" [23, 24]. Lipostasis is one of the important functions of these feedbacks. This feedback mechanism is shown schematically in the outer feedback loop in Figure 2. We discuss metabolic sensing in Section 3 of the review. Finally, in Section 4 we discuss the central neural networks that integrate this information and produce satiation. An important point reflected in Figure 2 is that current understanding indicates that the GI nutrient sensing and metabolic-sensing neural networks converging in the caudal brainstem, which also organizes the motor control of satiation. Note that current understanding indicates that this indirect feedback loop controls meal size by converging on the central neural networks mediating the direct control of satiation.

Figure 2 also shows several other controls of meal size that we do not include in this review. For example, although "hunger" mechanisms such as ghrelin contribute primarily to meal initiation, they also affect meal size [25]. Their contribution to homeostatic eating, however, is less clear. "Hedonics" refers to the pleasurable aspects of orosensory food stimuli. Food hedonics can tonically increase meal size and lead to increased adiposity [26-28]. In the modern western "obesogenic" environment [27, 28], these effects more often detract from homeostasis than contribute to it. The same is true of several stressors that primarily affect meal size $[25,29,30]$.

Our review is not comprehensive; rather, we review only what we consider what are presently the best-understood mechanisms of satiation. Finally, we also emphasize that most, probably all, of the physiological controls of meal size that we review are powerfully modulated, first, by sex and, second, by experience. We do not review these topics; the interested reader is referred to [31] and [32$36]$, respectively. 


\section{GI nutrient sensing and satiation}

\section{Which GI nutrient-sensing mechanisms contribute to satiation?}

In this section we review molecular GI nutrient-sensing mechanisms and $\mathrm{Gl}$ hormone-signaling mechanisms involved in satiation. GI nutrient sensors contribute to the control of eating through three mechanisms. First, they initiate neural signaling vagal and spinal visceral afferent nerves. The vagus in particular is a major route of information to between gut and brain. Vagal afferents project to the nucleus of the solitary tract (NTS) and via it throughout the dorsal vagal complex (DVC) of the hindbrain, an important node in the central neural network controlling eating. Second, GI nutrient sensors stimulate enteroendocrine cells in the $\mathrm{Gl}$ mucosa to release a variety of hormones with roles in digestion, metabolism and the control of eating. Our review concentrates on three with putative roles in satiation, cholecystokinin (CCK; secreted by I-cells), glucagonlike peptide-1 (GLP-1; secreted by L-cells), and peptide YY (PYY; secreted by Lcells). CCK acts locally on GI vagal afferents to signal satiation; PYY affects the brain directly; and GLP-1 acts both peripherally and centrally.

The apical surfaces of the enteroendocrine cells contact the gut lumen, whereas the basolateral surface contacts the lamina propria, in close proximity to the circulatory and lymphatic systems. Because of this "open-type" morphology, these cells are in perfect position to sense incoming nutrients as they arrive in the gut lumen, perform intracellular integratory operations, and generate a response in the form of hormone secretion. As in other endocrine cell types, alterations in membrane potential are coupled via voltage-gated $\mathrm{Ca}^{++}$entry to the release of secretory vesicles. All enteroendocrine cell types studied to date are also responsive to signals that activate G-protein coupled receptors. Finally, GI nutrient sensors affect the enteric nervous system. Enteric nervous system reflexes, often involving $\mathrm{Gl}$ hormones, regulate GI nutrient flow during and after eating by mixing, propelling and separating luminal contents. The regulation of gastric emptying is an especially important function that indirectly affects eating.

GI carbohydrate sensing. A variety of pathways have been implicated in the physiological responses of the gut to carbohydrates. The most information concerns glucose transporters, which can be coupled to $\mathrm{Na}^{+}$(e.g., SGLT1) or facilitative transporters (e.g., GLUT1, GLUT2, GLUT5). SGLT1 on the apical surface of enteroendocrine cells $[37,38]$ contributes to glucose absorption via $\mathrm{Na}^{+}$-dependent active transport. The $\mathrm{Na}^{+}$gradient is maintained by the sodiumpotassium pump located on the basolateral membrane surface. Glucose uptake is therefore a secondary active-transport system in which ATPase indirectly provides the energy. SGLT1 mRNA is increased by high-carbohydrate meals [39]. SGLT up-regulation was abolished in rats following chemical vagal deafferentation [40], suggesting a role of the vagus in carbohydrate uptake by enteroendocrine cells. 
Release of GLP-1 from L-cells and glucose-dependent insulinotropic peptide (GIP) from K cells is stimulated by activation of SGLT1, as indicated by its blockade by the inhibitor of sodium-coupled uptake, phloridzin [41, 42]. Interestingly, GIP secretion requires nutrient absorption, whereas GLP-1 secretion is triggered just by presence of nutrients in the lumen.

SGLT1 mRNA is found at relatively high levels in K-cells and in L-cells in both the small intestine and colon $[43,44]$ and in the mouse colon [45]. SGLT3 has been implicated in glucose-triggered serotonin release from rat enterochromaffin cells and downstream activation of vagal afferents via serotonin 3 receptors $[46,47]$. Thus, using phosphorylated Ca/CAMKII (pCAMKII) as a marker of cells activated by elevated $\mathrm{Ca}^{++}$, Vincent and colleagues found that pCAMKII was detectable in rat enterochromaffin cells and in vagal-afferent cell bodies following luminal application of glucose, but not galactose [48]. However, full characterization of the substrate preferences of mouse SGLT3a and the rat SGLT3 isoforms is clearly required before it will be possible to use substrate and inhibitor pharmacology as reliable indicators of rodent SGLT3 activation.

Dietary fructose stimulates GLP-1 secretion. Apical fructose transport in the intestine occurs via the facilitative sugar transporter GLUT5, whose activity is not electrogenic and has not been linked directly to activation of intracellular signaling pathways. Thus, thee molecular identity of the GLUT5 sensor and how fructose triggers GLP-1 release in vivo remains obscure. L-cells express high levels of GLUT5 mRNA [44], suggesting they can take up fructose from the intestinal lumen. However, while absorbed fructose could enter the metabolic pathway, with consequent generation of ATP and closure of KATP channels, it seems unlikely that this accounts for fructose-triggered GLP-1 release in vivo, as the simple closure of KATP channels by sulphonylureas is not a sufficient trigger for secretion [49]. Perhaps the enhanced metabolic rate may generate additional signals, including ATP itself, that stimulate GLP-1 secretion.

The sweet-taste receptors $\alpha$-gustducin and T1R2/T1R3 also contribute to glucose sensing in enteroendocrine cells, particularly K- and L-cells. $\alpha$-gustducin knock-out mice showed reduced levels of both GLP-1 and GIP compared to wildtype mice [50]. However, expression profiling of purified K- and L-cells revealed no enrichment of mRNA for T1R2/T1R3 or $\alpha$-gustducin in response to glucose $[43,44]$. In humans, however, intragastric infusion of the T1R2/T1R3 sweetreceptor inhibitor lactisole reduced the GLP-1 response to glucose in humans $[51,52]$, indicating that T1R2/T1R3 sweet receptors mediate part of the direct effect of carbohydrates on GLP-1 secretion. Clearly, further work is required to clarify the roles of sweet-taste receptor in GI hormone secretion.

The last step of absorption, basolateral glucose efflux, is facilitated by GLUT2 in the proximal GI tract and by GLUT1 more distally [45]. GLUT2 is transiently recruited to the apical-membrane surface after meals, allowing passive absorption of glucose at higher luminal glucose concentrations. Mace 
and colleagues [53] reported that sucralose doubled the rate of glucose absorption by increasing the expression of GLUT2. T1R2/T1R3 can act as a glucose sensor at high concentrations and may control the apical expression of GLUT2 and consequent increased capacity to absorb glucose.

GI lipid sensing. Ingested lipids are potent stimuli for the secretion CCK, GIP, GLP-1 and PYY. Although enteroendocrine cells may sense triglycerides, most evidence indicates that prior lipolysis is required [54]. Long-chain fatty acids (LCFA; 12 carbons or more) are potent CCK secretogogues [55, 56]. Vagal stimulation that is required for these responses by LCFA has been attributed to an indirect process, whereby the FFA are sensed by I cells and the release of CCK acts in a paracrine manner to stimulate $\mathrm{CCK}_{1}$ receptors on the vagal afferents. For lipid-induced CCK release, chylomicron formation is essential for this process. Pluronic L-81 or specific inhibitors of microsomal triglyceridetransfer protein inhibit chylomicron formation and reduce CCK secretion [56]. Since enteroendocrine cells cannot produce chylomicrons, it is possible that neighboring enterocytes serve as lipid sensors. Chylomicron synthesis does not seem to play a role in fat-triggered GLP-1 and PYY release.

All free fatty acids (FFA) receptors (FFAR 1-3, GPR120) are G-protein coupled receptors (GPCRs) [57-60], and enteroendocrine cells express their mRNA [43, 44, 61]. Medium- and long-chain fatty acids activate FFAR1 (GPR40) and GPR120, which stimulate the Gq-phosphatidylinositol pathway, increasing $\mathrm{Ca}^{++}$concentrations and exocytosis [57, 59]. Knocking out FFAR1 in mice decreases high-fat diet induced GLP-1 and GIP release [62] and impaired linoleic-acid-stimulated CCK secretion [63]. In vitro siRNA-knockdown of GPR120 reduced both GLP-1 and CCK secretion [59, 64].

FFAR2 (GPR43) and FFAR3 (GPR41) are present in the distal intestine, especially the colon. Small chain fatty acids (SCFA), which can activate GPR43 via either the $\mathrm{Gq}$ phosphatidylinositol or Gi/o pathways or GPR41 via Gi/o pathway [60], are involved in colonic release of GLP-1.

GPR119 is in a special category because lipids do not activate it, but oleolethylamine (OEA) does [65]. GPR119 is present in L- and K-cells [43, 44] and participates in GLP-1, PYY and GIP release [66]. Ingestion of nutrients stimulates the release of OEA in the small intestine, which can induce the release of GLP-1 [67].

Finally, CD36 is a transporter for free-fatty acids that was initially described in taste papillae [68-71]. It is believed to act via Src-PTK-B, PLCb2 and TRPM5 and as a co-receptor for GPR120 [72]. CD36 is expressed in the brush border of duodenal and jejunal epithelia. CD36-knockout mice have reduced OEA production and OEA-induced satiety [73], the latter of which can be induced via PPAR $\alpha$ activation $[73,74]$. 
Gl protein and amino acid sensing. The most information on protein sensing relates to CCK secretion. In vitro experiments using the STC-1 cell line indicate that CCK expression in response to peptones is mediated via GPR93 [75]. Although it has been shown that GPR93 recruits Gq-, Gs-, Gi- and G12/13mediated signaling pathways [76-78], its role in physiological peptone sensing is still under investigation. L-glutamate seems to act via the heterotrimeric T1R1/T1R3 receptor [79, 80], which is expressed in enteroendocrine cells [81]. Lphenylalanine couples with the CaSR receptor to activate a phosphatidylinositol pathway, which results in $\mathrm{Ca}^{++}$-induced release of hormones including CCK [63, 82, 83].

In vitro studies using the GLUTag, NCl-H716 and STC-1 cell lines show that peptide transporters such as PepT1 (SLC15A1) and PepT2 (SLC15A2) are activated by protein hydrolysates, resulting in increased intracellular $\mathrm{Ca}^{++}$and hormone release. Glutamine stimulation, for example, leads to release of GLP-1 from GLUTag and primary colonic cultures.

\section{What neuroendocrine mechanisms mediate Gl satiation?}

Vagus nerve. The importance of vagal afferents in satiation is reflected in the increase in meal size that follows selective surgical section of sensory abdominal vagal afferents. Considerable effort has been devoted to determining the brainstem organization of GI vagal afferent projections. The NTS is the first synaptic site for $\mathrm{Gl}$ afferents of the $9^{\text {th }}$ and $10^{\text {th }}$ cranial nerves (i.e, glossopharyngeal and vagus nerves, respectively). Reconstruction of these projections in the horizontal plane reveals a viscerotopic map, with the rostrocaudal distribution of terminal fields corresponding to their rostrocaudal origins in the GI tract. Furthermore, gastric and small-intestinal afferents project mainly to the commissural and medial nuclei of the NTS. In addition, several brain areas including the medial frontal cortex, insular cortex, central nucleus of the amygdala, paraventricular nucleus of the hypothalamus, lateral hypothalamic area and others, can influence the output of the NTS by virtue of their connectivity with the dorsal vagal complex, and thus be involved in the control of normal digestive processes.

The dorsal motor nucleus of the vagus (DMN) is the major source of visceral efferents that make synaptic contact with postganglionic neurons located in the myenteric plexus of the intestinal wall. A viscerotopic organizational map also exists here, with the neurons innervating the small intestine being localized in the medial part of the nucleus.

GI peptides and satiation: Introduction. Peptides secreted from the enteroendocrine cells of the small intestine signal negative-feedback information from meal-related food stimuli from the periphery to the brain. Although many GI peptides are hypothesized to have satiation effects, for most of these, the physiological status of their satiation action is uncertain. Natural physiological 
endocrine effects are assessed using six criteria (a) the plasma levels of the molecule change during meals; (b) cognate receptors for the molecule are expressed at its site of action; (c) administration of the molecule to its site of action in amounts that reproduce prandial levels at that site are sufficient to cause satiation; (d) compounds eliciting the secretion of the molecule produces effects similar to its administration; (e) the inhibitory effects on eating occur in the absence of abnormal behavioral, physiological, or subjective side effects; and (f) premeal administration of selective agonists and antagonists to the receptors for the molecule produce effects on eating consistent with their receptor pharmacologies; for example, an antagonist should delay eating if the molecule's role is to initiate eating or cause an increase in meal size if the molecule is regarded as a meal termination signal. These six criteria are considered below for CCK, GLP-1 and PYY.

CCK. CCK is released from the duodenal and jejunal l-cells in response to nutrients. In 1973, Gibbs, Young and Smith reported that intraperitoneal injections of CCK-8 rapidly decreased food intake in rats [84]. The effect seemed specific because CCK-8 did not decrease water intake and it did not produce signs of malaise. The mode of action off CCK-8 on eating in rats was originally thought to be endocrine, a hypothesis based on other models of peptide action (e.g., pancreatic enzyme secretion). Moreover, in monkeys and humans [85] CCK plasma levels increase soon after meal onset. Subsequent research in rats disconfirmed this hypothesis because (a) plasma CCK did not increase during meals in rats; (b) much more CCK-8 had to be infused intravenously to inhibit eating than to, for example, stimulate pancreatic exocrine secretion [86]; (c) intravenous infusion of a monoclonal antibody to CCK abolished the pancreatic response to food, but it did not change eating, whereas a small-molecule CCK receptor antagonist did increase eating [87]; and (d) the inhibitory potency of CCK-8 was markedly reduced or abolished after infusion into the portal vein or into the systemic circulation [88-90]. Thus, it was concluded that CCK-8 inhibits food intake in rats through a paracrine mode of action. More recently, it has been shown that the endogenous form of CCK is CCK-58, and it and other larger forms of CCK were much more potent than CCK-8 when administered systemically, suggesting that CCK-58 may act in part via an endocrine mode of action in rats, as well.

Local infusion experiments indicate that CCK acts in the area of the pylorus and proximal duodenum to elicit satiation in rats [91]. Selective abdominal vagal deafferentation further identifies the vagus as the route of the CCK satiation signal to the brain.

Intravenous CCK infusion was first reported to decrease eating in humans by Kissileff and colleagues in 1981 [92], but in view of the relatively high doses, however, it was uncertain whether the effects were physiological. Follow-up studies using clearly physiological infusion concentrations, however, indicated that that CCK decreased eating in both lean and obese subjects without illness or 
other adverse effects [85, 93]. Another crucial criterion for physiological function, that antagonism reverses the satiating effect of the exogenous peptide and, when administered alone, stimulates eating, was soon fulfilled in both rats and humans $[94,95]$.

CCK's satiating effects are mediated through interactions with CCK1 receptors [96-100]. The Otsuka Long-Evans Tokushima Fatty rat (OLETF) rat bears a spontaneous mull mutation of the CCK1 receptor gene and is hyperphagic and obese [101, 102]. Moran and colleagues found that OLETF rats consumed larger meals and did not decrease eating after CCK injections [103]. OLETF rats also showed a deficit in their eating responses to dietary fat, in that they did not quickly compensate when switched to a high-calorie/high-fat diet, leading to an exacerbation of their hyperphagia [104], nor did they reduce intake in response to intragastric loads of fat [104]. Covasa and Ritter (2001) extended these findings by showing that OLETF rats have deficits in the satiation response to a variety of intestinal nutrient infusions and, when reductions in intakes were present, CCK1 receptor antagonists did not affect them. However, work by $\mathrm{Bi}$ and Moran indicates that much of the eating phenotype of OLETF rats stems not from loss of intestinal CCK signaling but from loss of neuronal CCK signaling via $\mathrm{CCK}_{1}$ receptors in the paraventricular nucleus of the hypothalamus.

Importantly, treatment with $\mathrm{CCK}_{1}$ receptor antagonists decreased the satiating potency of ingested food, but did not abolish it. Thus CCK must interact with other mechanisms to control eating. Synergistic interactions between CCK and several other negative-feedback signals have been identified, including orosensory nutrient stimuli [105], gastric volume [106], leptin [107], smallintestinal serotonin [108, 109], apolipoprotein AIV [110], pancreatic glucagon [111], amylin [112] and insulin [7].

CCK also changes the expression of a number of peptides and receptors in the abdominal vagal afferents, although these have not been shown yet to be part of CCK satiation. For example, CCK-8 increases the expression of cocaine and amphetamine receptor transporter (CART) [113] and decreases the expression of $\mathrm{MCH}$ [114] in the vagus. Finally, studies using c-Fos expression as an indicator of neuronal activity showed that in addition to the dorsal vagal complex, CCK-8 also activates neurons in the ventrolateral medulla, parabrachial nucleus and forebrain nuclei including the central nucleus of the amygdala, paraventricular, dorsomedial and arcuate nuclei of the hypothalamus. The roles of these presumably polysynaptic projections in the processing and integration of the peripheral information produced by peripheral CCK through the stimulation of vagal afferent fibers is still under investigation.

GLP-1. Peripheral GLP-1 is secreted from enteroendocrine L-cells located mainly in the jejunum, ileum and colon. However, duodenal food stimuli can elicit GLP-1 secretion via neurohumoral reflexes mechanisms, which most likely lead to the increases in GLP-1 plasma levels rise within minutes of the onset of meals. 
The vagus is an important component of these reflexes: (a) glucose- and fatinduced GLP-1 release was greatly reduced in rats by bilateral subdiaphragmatic vagotomy [115], and (b) postprandial GLP-1 secretion was blocked by pharmacological blockade of vagal signaling with muscarinic receptor (M1 and M2) or gastrin-releasing peptide antagonists [116]. Both M1 and M2 muscarinic receptor subtypes are expressed in L-cells and are thought to mediate neural regulation of GLP-1 secretion [116].

The GLP-1 receptor is a G-protein coupled protein and is expressed widely throughout the periphery (enteric nervous system, vagal nerves, stomach, small and large intestine, adipose tissue, kidneys, etc.) and the brain. Whether GLP-1 acts in the periphery, in the brain or both to elicit satiation is not entirely clear. In the periphery it probably acts at least in part in a paracrine manner in rats because intraperitoneal GLP-1 infusion decreased eating in a situation in which intraportal GLP-1 infusion did not [117]. Furthermore, once GLP-1 is released from the L-cells is rapidly degraded by the enzyme dipeptidyl peptidase IV (DPP-IV), which is expressed on capillary vessels throughout the body. If GLP-1 survives the degradation by DPP-IV it may reach GLP-1 receptors in the brain where it may act to elicit satiation.

Additional evidence that GLP-1 acts in the periphery to elicit satiation comes from antagonist studies showing that central administration of the potent and selective GLP-1 receptor antagonist exendin (9-39) did not block decreases in eating produced after peripheral administration of GLP-1, but did block decreases in eating after central injection of GLP-1. Moreover, exendin (9-39) administered in the periphery blocked the decreases in eating caused by endogenous GLP-1 secreted in response to intestinal nutrient infusions and peripheral GLP-1 administration. The enteric nervous system or the vagal afferents could be sites where peripheral GLP-1 can act. This is supported by evidence that subdiaphragmatic vagotomy abolishes the satiating action of intraperitoneal GLP-1 infusion, although not that of GLP-1 infusion into the hepatic portal vein.

GLP-1 is also synthesized by neurons of the nucleus tractus solitarius, which then project to forebrain structures including the hypothalamus, hippocampus and cortex, all of which express GLP-1 receptors. The relative contribution of central and peripheral GLP-1 to central GLP-1 receptor stimulation remains a matter of active research. For example, although GLP-1 administration in the lateral or fourth ventricle in inhibits eating, the caudal brainstem, however, is sufficient for the inhibitory action of GLP-1 on eating because intraperitoneal or fourth ventricular injections of GLP-1 elicit satiation in decerebrate rats. Both peripheral and central injections of GLP-1 induce c-Fos expression in the PVN, and GLP-1 injections in the paraventricular nucleus, but not the arcuate, decrease eating, suggesting that peripheral and central injections of GLP-1 may decrease eating via different neuronal mechanisms. Local peripheral infusions of 
exendin (9-39), such as done with CCK receptor antagonist, would be very helpful in resolving this issue.

High fat diet decreases the eating-inhibitory effect of GLP-1 by diminishing its meal-related secretion or by reducing the number of L-cells in the small intestine. Obese subjects also show increases in DPP-IV activity.

GLP-1 decreases eating by reducing meal size, rather than meal frequency. Meal size was decreased when GLP-1 was 5 min GLP-1 infusions were administered at the onset of the first meal size in spontaneous eating rats [118]. Chelikani [119] and colleagues, however, showed that 3-h intrajugular infusions of GLP-1 decreased both meal size and meal frequency. This discrepancy in results may be due to the fact that Chelikani and colleagues used a less physiological approach by administering GLP-1 by constant infusions.

PYY. PYY is secreted mainly by the same L-cells that also secrete GLP-1. As with GLP-1 the secretion is biphasic, initially stimulated by atropine-sensitive neural projections from the proximal small intestine, followed by direct nutrient stimulation. Also like GLP-1, it is secreted mainly in response to lipids and carbohydrates. PYY (1-36), the secreted form, is inactive until proteolyzed to PYY (3-36) by DPP-IV. In the periphery, PYY 3-36's effects on eating arise from its interactions with inhibitory GPCR Y2R receptors.

Batterham et al. [120] initially reported that intravenous infusion of PYY (336) reduced eating in humans. The design was unusual, however, in that infusions were done during the intermeal interval and plasma PYY (3-36) levels had returned to basal levels before the test meal, thus limiting its use as a satiation test. It also remains unclear whether physiological doses of PYY (3-36) are sufficient to acutely inhibit eating in rats or humans. Beglinger and coworkers $[121,122]$ found that only PYY (3-36) infusions that elicited plasma PYY (3-36) concentrations greater than those elicited by a large meals inhibited eating in humans. Furthermore, PYY (3-36) infusion often led to nausea, suggesting that the decreases in eating may simply represent a nonspecific aversive effect. In contrast, meal-contingent PYY (3-36) infusions reduced meal size in rats in the absence signs of aversion [123]. Furthermore, Abbott and colleagues (2005) [124] reported that injection of a $Y 2 R$ antagonist into the arcuate nucleus reduced the effect of intraperitoneal PYY (3-36) injection and when given alone increased eating, which both further supports the hypothesis that endogenous PYY (3-36) is a normal physiological satiation signal and suggests the arcuate nucleus of the hypothalamus as its site of action. That may not, however, be the only site of action because the vagus also expresses $Y 2 R$, and vagotomy was reported to block the effect of intraperitoneal injections of PYY (3-36) [125]. 


\section{Brain metabolic sensing and satiation.}

\section{Introduction.}

As described in Section 1 and Figure 2, energy homeostasis is regulated by feedbacks from circulating energy metabolites and hormones involved in energy metabolism and energy storage, which act on a widely distributed set of peripheral and central neurons, dubbed as "metabolic-sensing neurons". Many of these signals, for example blood glucose, reflect meal-related increases in absorption, energy metabolism (e.g., tissue glucose uptake, gluconeogenesis, etc.) and energy storage (blood glucose is usually increased in obesity). Others, for example FFA and leptin, may reflect mainly energy storage. We focus on brain metabolic-sensing neurons, for which the most information is available.

Identification of metabolic sensors is a classic aspect of the study of homeostatic eating. Until recently, however, this research largely neglected how these mechanisms affect meals, relying instead on measures of total food eaten over days or longer periods. As a result, the evidence that these feedbacks selectively control satiation was mainly indirect, based on the overwhelming evidence that the homeostatic control of eating is affected mainly by changes in meal size, summarized in Section 1. This disconnect between homeostatic control mechanisms and behavior is reflected in our review. Happily, however, recent work has begun not only to remedy this error, but to reveal the neural mechanism through which metabolic nutrient-sensing and GI nutrient sensing converge to generate an integrated satiation signal.

\section{Which brain metabolic-sensing neurons contribute to satiation?}

Introduction. Research beginning 60 y ago has identified and characterized the activity of metabolic-sensing neurons in the hypothalamic arcuate, ventromedial nucleus and lateral hypothalamic area. More recently, metabolicsensing neurons also have been identified in the caudal brainstem [126]. According to the theory, when extracellular levels of the sensed metabolites or hormones reach a certain level, these neurons become either excited or inhibited and set in motion neural networks that control eating, energy expenditure and metabolism. As our review reflects, however, demonstrations that metabolicsensing neurons play a normal phasic or tonic physiological role in the control of meal size are still lacking.

Brain glucose sensing. Jean Mayer's [127] classic glucostatic theory posited that brain glucose utilization controls eating. Since then, important milestones including identifying potassium as a key player in this process [127], electrophysiological recordings from ventromedial and lateral hypothalamic neurons that were glucose-excited or glucose-inhibited [128-130], and further characterization of the $\mathrm{K}^{+}$-channel involved in neuron's response to glucose [131] 
provided a solid basis for experiments in the last two decades aimed identifying how neurons sense glucose and their roles in health, obesity and diabetes.

Ventromedial and arcuate nuclei glucose-sensing neurons alter their action-potential frequency in response to changes in extracellular levels of glucose [132, 133]. Glucose-excited (GE) neurons increase while glucoseinhibited (GI) neurons decrease their action-potential frequency in response to increases in extracellular glucose from 0.1-2.5 mM glucose [132]. Thus, their dynamic range spans the normal range of extracellular glucose levels in the brain, which are about $\sim 10 \%$ of systemic blood glucose levels [134], and they are plausible normal physiological controls of eating. GE neurons require glucose metabolism for excitation [133, 135, 136], however, GI neurons comprise distinct populations, which either require glucose metabolism [135, 136] or sense the glucose molecule directly [137].

GE neurons sense glucose by a mechanism analogous to that operating in pancreatic $\beta$-cells [133]. Glucose enters the cell via GLUT-2 transporters, is phosphorylated by glucokinase (GK), and is metabolized in the TCA cycle to increased intracellular levels of ATP. ATP inhibits ATP-inhibited $\mathrm{K}^{+}$channels ( $\mathrm{K}_{\mathrm{ATP}}$ channels) and the resultant $\mathrm{Ca}^{++}$influx depolarizes the cell [138]. The concentration-response relationship for both $\mathrm{K}_{\text {ATP }}$ channel currents and actionpotential frequency of ventromedial nucleus GE neurons are steep, linear relationships for glucose concentrations between 0.1 and $1.5 \mathrm{mM}$ glucose. The slope then decreases sharply and the concentration-response function plateaus between 2.5 and $5 \mathrm{mM}$ glucose [139], i.e., well above physiological levels. These data strongly suggest that the $\mathrm{K}_{\text {ATP }}$ channel on GE neurons plays an important role in physiological brain glucose sensing. Current data suggest that there may be multiple subtypes of GE neurons utilizing alternate glucose-sensing strategies, for example sensitive or not sensitive to the $\alpha$-subunit of AMPK, an important cellular fuel gauge $[140,141]$.

The phenotype of arcuate nucleus GE neurons remains controversial. Some studies showed that the electrical activity of pro-opiomelanocortin (POMC) neurons stimulated with glucose is consistent to that of GE neurons [140, 142] and correlated with changes in energy status [143]. Several observations, however, indicate that POMC neurons are not GE neurons: (1) GE neurons are not present in the region of the arcuate nucleus generally designated as the location of POMC neurons [139]; (2) immunohistochemical evaluation following electrophysiological recordings from GE neurons did not reveal POMC-positive neurons [139]; and (3) intracarotid glucose injections did not increase levels of cFos expression in POMC neurons [144].

GI neurons sense glucose differently than GE neurons. Although GLUT-2 and GK are also involved, [135, 136, 145], the downstream cascade clearly involves AMPK [146], whose activation leads to NO production and CAMKK 
activation [147], leading to depolarization of the GI neurons in response to decreased glucose [146].

The physiological relevance of $\mathrm{GE}$ and $\mathrm{Gl}$ neurons is uncertain. Experiments performed in the early 1990s showed that a $5-10 \%$ decline in blood glucose levels occurred $12-5$ min preceding spontaneous meals in rats and that blocking the decline with glucose infusions delayed meal initiation, providing a causal relationship of declines in glucose and the onset of the meal [148]. A problem with this evidence is that changes in blood glucose do not necessarily reflect changes in brain glucose. When Levin and colleagues [134] measured glucose in the blood and the ventromedial hypothalamus in spontaneously eating rats they failed to find a clear relationship between ventromedial hypothalamus glucose changes and either the onset or termination of spontaneous meals or between blood glucose and ventromedial hypothalamus glucose before meals. These elegant experiments exemplify how high the bar is to unambiguously demonstrate a normal physiological role of neuronal signaling in eating, a point which should be kept in mind in the following discussion of other metabolicsensing mechanisms and of the neural networks controlling eating.

Finally, it is also important to note that (a) that the emergency eating response to acute biochemical hypoglycemia involves ventromedial hypothalamus glucosensing mediated by GK [134], and (b) it remains possible that glucose sensing in the portal vein or liver does contribute to the physiological control of meal size $[149,150]$.

Brain lipid sensing. Oomura [151] suggested that FFA might have a facilitatory effect on glucose-sensitive neurons in the lateral hypothalamus. Wang et al. [152] later showed that there are oleic acid-excited and oleic acid-inhibited neurons in the arcuate nucleus whose activity depended on the extracellular glucose concentration. Le Foll et al., [153] showed that $\sim 40 \%$ of ventromedial hypothalamic neurons were excited and increasing concentrations of oleic acid inhibited $30 \%$, but that their activity was not dependent on ambient glucose concentrations. Furthermore, inhibition of acyl-CoA synthetase, the initiating step in fatty-acid metabolism, manipulations of CPT1 activity and reactive oxygen species formation, or blockade of KATP channel activity or the fatty acid transporter CD36 reduced activity of only $20 \%$ of the excitatory and $40 \%$ of the inhibitory oleic-acid sensitive neurons, suggesting that oleic acid levels rather than utilization affected ventromedial hypothalamus neuronal activity through multiple pathways. FFA sensing by CD36, or fatty-acid translocase/CD36, is especially interesting because CD36 is a membrane FFA receptor/transporter that does not require intracellular FFA metabolism to initiate signaling. In confirmation of the importance of such signaling, Moulle et al., [154] demonstrated that the eating-inhibitory effect of $10 \mathrm{~min}$ intracarotid Intralipid infusions was dependent on expression of CD36 in the VMN and on acylCoA synthesis, but not on fatty-acid oxidation. 
The initial tests of brain lipid sensing and eating neuronal involved intracerebroventricular injections of the fatty acid synthase inhibitors C75 and ceruleinin, which decreased eating and body weight in mice $[155,156]$. The underlying lipid sensing mechanism is unclear. Some data suggest $C 75$ reduces eating by decreasing PAMPK [157]. Obici et al. [158] extended these findings by showing that intracerebroventricular administration of oleic acid decreased eating, in part, by decreasing hypothalamic expression of neuropeptide Y (NPY) [158]. Rossetti et al. then suggested that fatty-acid synthase inhibitors and the intrahypothalamic oleic acid infusions lead to an accumulation of long-chain fatty acid (LCFA) CoAs in the hypothalamus that, via a negative-feedback mechanism, signal lipid availability and inhibit eating. Indeed, inhibition of CPT-1 in the arcuate nucleus increased levels of oleyl-CoA and was accompanied by low levels of agouti-related peptide (AgRP) and NPY mRNA levels [159]. Interestingly, intrahypothalamic oleic acid did not decrease eating or increase NPY mRNA expression in rats fed high-fat diet [160].

The physiological relevance of brain lipid sensing has not been directly tested. Because plasma FFA levels do not rise during meals, they are unlikely to serve as phasic satiation signals related to ongoing meals. FFA levels do rise in obesity [161], suggesting a possible role as a tonic weight-regulatory satiation signal. If so, however, the brain must combine this information with other metabolic sensing because FFA levels also rise during fasting.

Another issue with brain lipid utilization sensing is that the brain fatty-acid oxidation occurs in astrocytes, not neurons [162-164]. It is therefore possible that brain lipid sensing is based on neuronal uptake of ketone bodies produced in astrocytes. Le Foll et al. [24] using electrophysiology and microdialysis techniques, confirmed this hypothesis by showing that (a) plasma and ventromedial hypothalamic plasma beta-hydroxybutyrate levels were higher in rats during the first hour of high-fat diet feeding following an overnight fast, (b) as ketones can have an overriding, excitatory action on either glucose or oleic-acid stimulation of ventromedial hypothalamic neurons, the rats decreased eating, and (c) this eating-inhibitory effect was reversed by inhibition of ketone production by 3-hydroxy-3-methylglutaryl-CoA synthase inhibitor.

Brain amino acid sensing. Initial studies by Cota and colleagues [165, 166] suggested an important role for hypothalamic leucine sensing and downstream changes in mTOR and S6K1 in the control of eating and body weight, as well as during diet-induced obese states. Work by Blouet and colleagues [126, 167, 168] has begun to unravel the eating effects of leucine sensing in ventromedial and arcuate nuclei of the hypothalamus and NTS in the control of eating. They demonstrated that: (a) in the fasted rats, cerebrospinal fluid leucine concentrations were 26 times lower than plasma leucine levels; (b) ingestion of a high-leucine meals raised the CSF leucine levels; (c) intraventricular infusions of leucine in the $3^{\text {rd }}$ or $4^{\text {th }}$ ventricle decreased eating; (d) $3^{\text {rd }}$ ventricle injection of inhibitor of leucine metabolism (i.e., ketogenesis) decreasing eating. These data 
strongly support the hypothesis that brain leucine sensing can physiologically control eating, at least under certain dietary conditions. An interesting point was that $3^{\text {rd }}$ ventricle leucine injections did not affect meal size after the first meal, but led to a large decrease in meal frequency, whereas $4^{\text {th }}$ ventricle leucine injections decreased meal size and not meal frequency. This suggests that NTS leucine sensing may be more important for the tonic contribution of satiation related to energy homeostasis than ventromedial/arcuate nuclei leucine sensing.

Brain insulin sensing. The hypothesis that insulin might provide a tonic signal linking adipose-tissue energy stores to the control of eating arose from (a) Bagdade et al.'s [169] reports that both basal, fasting insulin levels and glucosestimulated insulin levels are linearly correlated to adipose-tissue mass, which they estimated by percent ideal body weight, and (b) a similar correlation between body weight and basal insulin in rats [170]. Insulin, as with leptin, has been demonstrated that it regulates eating. Plasma insulin is low during fasting and increases mainly during and after meals. Both basal and prandial insulin levels are direct functions of the amount of white adipose tissue in the body [169] [171, 172]. Soon after Woods et al. [173-175] reported that insulin infusions into the 3rd ventricle or near or directly within the mediobasal hypothalamus decreased eating and body weight in baboons and rats. The responses are dosedependent [173, 174] and apparently not related to illness [176]. Further important discoveries included that: (a) insulin entered the brain; (b) brain insulin levels in the cerebrospinal fluid were higher in obese rats than lean rats; (c) insulin receptors exist in the brain; and (d) that insulin receptors exist on NPY/AgRP and POMC neurons in the arcuate nucleus as well as other brain areas implicated it the control of eating (for review, see [177]). Despite this wealth of data, however, the hypothesis that endocrine insulin functions as a normal physiological endocrine adiposity signal lacks crucial support: (a) whether physiological intravenous or central doses of insulin are sufficient to inhibit eating either acutely or tonically is not clear [178]; (b) although there are reports that acute central insulin antibody treatment increase eating [179], there are no demonstrations that chronic central insulin increases eating (there is a report that brain-specific transgenic deletion of insulin receptors increases eating and body weight in female mice, but this appeared not to be the case in males [180]; (c) basal levels of plasma insulin did not change in association with weightregulatory eating responses in rats recovering from forced overweight [181] and in other situations [182].

Brain leptin sensing. Leptin is an adipokine hormone secreted by the white adipose tissue. Leptin and leptin receptors were discovered in the search for the hormonal mechanism accounting for the hyperphagia/obesity phenotypes of the ob/ob (leptin-deficient, now known as Lep ${ }^{\mathrm{ob}}$ ) or $\mathrm{db} / \mathrm{db}$ (leptin receptor-deficient, Lepr $^{\mathrm{db}}$ ) mice [183, 184]. Circulating leptin is taken up into the brain [185], and leptin receptors are highly expressed in NPY/AgRP and POMC neurons in the arcuate nucleus as well as in the dorsal vagal complex and other areas [186188]. NTS neurons express leptin receptors, and $4^{\text {th }}$ ventricular and NTS 
injections of leptin inhibit eating, although whether this is a meal size effect hasn't been tested [189].

Basal leptin levels are linearly correlated to fat mass. Although plasma leptin levels display a marked circadian variation, they are not affected by individual meals, so that their relation with fat mass is maintained consistently [190]. Evidence suggesting that leptin is a tonic satiation signal includes: (a) three groups of investigators reported that doses of peripheral and central leptin that inhibited eating did so by reduced the size of rats' spontaneous meals, without affecting the number of meals consumed [191] $\left(4^{\text {th }}\right.$ ventricular and NTS injections of leptin inhibit eating [189], but whether this is a meal-size effect hasn't been tested); (b) chronic peripheral leptin treatment also reduced eating by selectively decreasing meal size $[13,14]$; and (c) the hyperphagia due to genetic impairments of leptin signaling in rats and mice were expressed as characterized by meal size specific alterations. Thus, the hyperphagia of ob/ob mice and Zucker rats (with deficits in leptin receptors) are both characterized by chronic increases in the size of spontaneous meals $[12,192]$. There is mixed support for the hypothesis that these effects reflect a normal physiological function: (a) physiological doses of leptin appeared sufficient to inhibit eating in mice [178]; (b) in obese humans tested after $10 \%$ weight loss, infusing leptin in amounts sufficient to reproduce pre-weight loss levels reversed subjective measures of meal-induced satiation [92]; (c) Infusion of a leptin-receptor antagonist over $1 \mathrm{wk}$ increased eating and weight gain [193]; (d) Moreover, when infused together with leptin, the antagonist prevented the anorectic and weightreducing responses to leptin, as well as the increase in leptin signaling gain [193]. Because the antagonist neither stimulated leptin-induced STAT3 phosphorylation (see below) nor reduced the basal levels of phosphorylated STAT3, Zhang et al. concluded that in both tests, the agent actively antagonized the rat leptin receptor. Whether plasma leptin levels encode adiposity information in all situations remains unclear, however, as several dissociations between adiposity, leptin levels and weight-regulatory eating have been reported [181, 182].

Leptin is a pleiotropic hormone that activates different intracellular signaling cascades in the brain. When it binds to the long, signaling form of its receptor $\left(\right.$ Lepr $\left.^{b}\right)$ it recruits the Janus Kinase (JAK). JAK binds to and phosphorylates Lepr ${ }^{b}$ [194], which activates STAT3. Once phosphorylated, STAT3 binds to pomc and agrp promoters, stimulating POMC and inhibiting AgRP expression $[195,196]$. Leptin via Lepr ${ }^{b}$ also activates PI3K, which induces the synthesis of PIP3 from PIP2 [143, 197, 198]. Accumulation of PIP3 leads to PDK1 activation, which further activates protein kinase $B$ (PKB, also know as AKT).

Interestingly, the leptin-signaling and insulin-signaling pathways converge in PI3K is activation [188, 199]. AKT, one of the PDK1 downstream targets, has an important role in the regulation and activation of many proteins and 
transcription factors, such as FoxO1 [200, 201], AMPK [140], and mTOR [165]. FoxO1 acts as an inhibitor of POMC expression [202]. Leptin and insulin also regulate the AMPK signaling pathway in the hypothalamus [140]. Proteins involved in this pathway are hypothesized to sense energy status and are activated by energy deficiency [203]. Leptin and insulin inhibit the activation of AMPK and its downstream targets.

The mTOR pathway is also thought to be involved in the hypothalamic regulation of eating, [165]. Intact mTOR signaling is necessary for the eatinginhibitory effect of leptin [165]. In contrast to AMPK, hypothalamic mTOR expression is higher in situations of energy surplus, perhaps mediated by both leptin [165] and insulin signaling [204].

\section{How does the brain integrate satiation feedbacks?}

\section{Introduction}

The neurochemical and neurophysiological characterization of the neural pathways underlying the effects of the hormone leptin on eating led to important insights into the neural networks controlling eating [205, 206]. In particular, both in the hypothalamus and the DVC in the caudal brainstem, neurons that responded to leptin were also activated by other metabolic and GI sensors. These findings established that the regulation of eating, energy expenditure and adipose tissue metabolism is mediated by a distributed integratory neural network involving bidirectional communications between the forebrain and hindbrain rather than by the hypothalamus alone. In this section we first review some of the key neurochemical signals involved in eating. An unfortunate aspect of this work is that it often does not link the functions described to meal control. Therefore we close by describing progress in understanding the convergence of forebrain neural networks on caudal brainstem control of networks mediating satiation.

Perhaps the most investigated neurons with respect to regulation of eating are the POMC neurons and neuropeptide Y (NPY)/AgRP neurons in the arcuate nucleus. POMC neurons project throughout the brain, where they release $\alpha$ melanocyte stimulating hormone $(\alpha-\mathrm{MSH})$, which binds to melanocortin receptors 3 and 4 (MCR3 and MCR4). NPY/AgRP neurons release AgRP, an $\alpha-M S H$ inverse agonist that acts at the MCR to counteract the effects of a-MSH. NPY exerts its effects on eating via NPY receptors (NPYR) (1, 2, 4 and 5), which are is independent of MCR. The discovery of this ARC microcircuit greatly accelerated the progress in understanding the neural control of eating, some of which we review below.

\section{POMC neurons.}


Mouse models of Pomc and Mc3r/Mc4r deficiency display hyperphagia and obesity [207-209]. Central administration of melanocortin receptor agonists dosedependently decreases short-term eating [210]. Both genetic and pharmacological studies suggest that long-term activation of the melanocortin system may chronically decrease eating and body weight. Indeed, transgenic mice overexpressing melanocortins show decreased eating and lower body weight-gain and adiposity than controls [211, 212]. Long-term effects on body weight have also been investigated using POMC-adeno-associated virus (POMC-AAV)-mediated overexpression at specific sites within the brain. For example, hypothalamic POMC-AAV expression in the arcuate nucleus, but not at other hypothalamic sites, was sufficient to reduce the hyperphagia in leptin deficient, obese rats [213]. POMC-AAV injections in the NTS and VTA also had the same inhibitory effect on eating and body weight gain in diet-induced obese rats [214, 215]. Aponte and colleagues [216] showed that optogenetic stimulation of POMC neurons in the arcuate nucleus was required for a long term (24 h) rather than a short term $(2 \mathrm{~h})$ to decrease eating. Although this does not agree with previous findings about the latency of POMC neuronal activation to reduce eating, some alternative explanations should be considered: (a) POMC peptides diffuse slowly to their targets in the brain, (b) activation of POMC neurons decrease eating only under certain conditions (e.g., the onset of the dark cycle), and (c) specific stimulation patterns may be required for POMC neurons to have effects on eating. Finally, (d) injections of a lentiviral gene-delivery vector carrying a gene construct for production of $\alpha-\mathrm{MSH}$ into the arcuate nucleus of the hypothalamus in mice led to a sustained attenuation of diet-induced obesity [217].

The NTS also contains a small, but functionally important number of POMC neurons $[218,219]$. To our knowledge, there is only pharmacological evidence that establishes the sufficiency of arcuate nucleus vs. NTS POMC neurons in the regulation of short-term eating. That is, Seeley and colleagues [220] demonstrated that injections of the non-selective MC4R antagonist SHU9119 into the $3^{\text {rd }}$ ventricle of rats increased 4 and $24 \mathrm{~h}$ food intake. However, they did not test the effects of the antagonist administration in conditions in which the $3^{\text {rd }}$ ventricle aqueduct was blocked, which would eliminate the possibility that the effect on eating was due to blockade of MC4R in the NTS. The necessity of arcuate nucleus POMC neurons in the regulation of short-term eating is still unclear.

In contrast to the case of the arcuate nucleus, more evidence supports a necessary role of the NTS POMC neurons in the regulation of eating behavior. Injections of the MC3/4R agonist MTII into the caudal brainstem are sufficient to decrease eating [221-223]. Furthermore, the effects on spontaneous eating following administration of MTII near the caudal brainstem or into the DVC are due to changes in meal size [224]. Using DREADD pharmacogenetic technology, POMC neurons were activated in either the arcuate nucleus or the NTS. Chronic, but not acute activation of arcuate POMC neurons reduced eating, and their 
ablation resulted in hyperphagia and obesity. In contrast, acute stimulation of NTS POMC neurons rapidly reduced eating, and ablating this POMC neuronal population did not produce any obvious changes in eating behavior or body weight [225]. These results are consistent with the view that the POMC neurons in the arcuate nucleus are critical for maintaining long-term energy homeostasis, and that the NTS POMC neurons contribute to short-term feeding control, i.e., probably in response to $\mathrm{Gl}$ satiation signals.

An interesting aspect in the identification of the segregation of roles between arcuate and NTS POMC neurons was revealed by a study performed by Zheng and coworkers, in which an adenoviral transfer vector expressing EGFP only when transduced into cre-expressing cells was used to exclusively label POMC neurons. They showed that unilateral injection of this tracer resulted in GFP-positive axon profiles in the NTS and other areas of the caudal brainstem. To determine the proportion of NTS terminating $\alpha-M S H$ fibers that arises from arcuate-POMC neurons versus NTS-POMC neurons, $\alpha-\mathrm{MSH}$ immunoreactivity in the NTS and vicinity of intact rats were compared to those of decerebrate rats. In intact rats, very fine axon profiles and a moderate number of relatively large caliber axon profiles were present throughout the NTS. By contrast, in decerebrate rats most of the larger caliber fibers were missing and only the fine immunoreactive fibers remained in this region [226]. These results suggest that NTS neurons are supplied with endogenous $\alpha-\mathrm{MSH}$ both by arcuate- and NTSPOMC neurons.

POMC neurons project to multiple brain sites, both intra- and extrahypothalamic. The network of the POMC circuit can be divided into leptin-, insulin- or serotonin-sensitive neurons [227, 228] and, to a lesser extent, leptinand insulin-responsive neurons [229]. To release bioactive signaling molecules, POMC neurons integrate afferent signals until a depolarization induces the release of peptidergic vesicles and granules in a calcium-dependent manner $[230,231]$. According to classically described mechanisms, boutons in presynaptic terminals should release neuropeptides onto other neurons expressing the appropriate receptors. Interestingly, peptides released from POMC neurons can be detected at sites devoid of post-synaptic receptors and at non-synaptic sites as well [232-235]. Accordingly, POMC neurons may participate both in synaptic and volume transmission in the brain [236, 237].

Given that POMC neuronal fibers are present around the ventricles through the entire rostrocaudal extent of the brain, an important aspect of these phenomena is that the neuropeptides released by POMC neurons can enter the cerebral ventricles and act at sites lacking direct POMC synaptic control [238240]. This possibility was confirmed by findings that ICV administration MTII can reduce or increase eating, respectively [241-243]. MTII reduced intake of scheduled glucose meals and of overnight spontaneous pellet intake [244]. These extended previous findings that MTII decreases eating during the dark phase [221, 222]. MTII selectively reduced in meal size and meal duration, with 
no change in meal frequency [244], suggesting that MTII reduces eating by increasing the satiating potency of negative-feedback signals critical to satiation. Interestingly, however, MTII did not affect the reductions in eating produced by intraduodenal glucose infusions [244], suggesting that MTII does not modulate the potency of $\mathrm{Gl}$ satiation signals. Thus, more work is required to determine the functional significance of $\alpha-\mathrm{MSH}$ signaling.

Central melanocortins have been proposed as downstream mediators of the effects of leptin [245]. The first evidence for this was a Seeley et al. [220] report that administration of the MC4R antagonist SHU9119 into the $3^{\text {rd }}$ ventricle just prior to a leptin injection completely blocked leptin's effect on eating. This appeared selective to leptin because SHU9119 did not block the effect of $3^{\text {rd }}$ ventricle administration of GLP-1 [220]. The interaction appears to occur within hypothalamic POMC neurons because they express leptin receptors [186] and leptin activates them, as shown both by increases in c-Fos expression [246] and by electrophysiological recordings [187]. Leptin administration in non-deprived rats increased POMC mRNA in the hypothalamus [247]. Mice selectively deficient for leptin receptors on POMC neurons were less obese than mice globally deficient in leptin receptors [248], and the difference developed as a result of decreased energy expenditure, rather than increases in eating behavior. Thus, MC4R signaling is selectively involved in leptin's effect on eating.

There are several indications that caudal brainstem MC4R contribute to the mediation of eating by hindbrain-delivered leptin. Caudal brainstem application of leptin decreased eating similarly to effects of $4^{\text {th }}$ ventricular or NTS injections of MTII [189, 249, 250], and this was reversed by MC4R antagonist pretreatment [249]. These data suggest that caudal brainstems MC4R are part of the downstream mediation of hindbrain-induced effects on eating. POMC-EGFP mice were used to investigate whether the NTS POMC neurons are also leptinsignaling neurons. This method has the advantage is that the POMC neurons can be unambiguously identified in the NTS, whereas immunocytochemical or in situ hybridization methods failed before. Systemic leptin induced pSTAT3 immunoreactivity in NTS POMC-EGFP neurons that were located mostly caudal to the AP [251]. These results indicate that NTS POMC neurons are leptinsignaling neurons.

Insulin's eating inhibitory effect may also involve POMC neurons. Injections of SHU9119 in the $3^{\text {rd }}$ ventricle attenuated the reduction in eating caused by $3^{\text {rd }}$ ventricular injections of insulin [252, 253], and after a prolonged fast, POMC expression in the arcuate nucleus was attenuated by insulin, consistent with previous findings that low levels on insulin in diabetic rats was accompanied by low levels of POMC expression and it is restored by systemic insulin treatment [253]. Insulin receptors are expressed on POMC neurons in the arcuate nucleus [252], although whether they are also expressed by POMC neurons in the NTS or other regions of the hindbrain has not been investigated. In the arcuate nucleus, insulin hyperpolarizes POMC neurons [140, 188, 227, 
254]. In contrast to the effect of leptin-receptor lesions, the selective ablation of insulin receptors in POMC neurons had no effect on eating [188]. In another study, however, when insulin receptors were re-expressed in insulin-receptor knock-out mice, food intake increased [255].

Numerous lines of evidence suggest that $5 \mathrm{HT} 2 \mathrm{CR}$ in POMC neurons constitute a key node governing eating: (a) POMC neurons in the ARC express $5 \mathrm{HT} 2 \mathrm{CR}$ and receive input from other $5 \mathrm{HT}$-immunoreactive terminals [256, 257]; (b) 5HT2CR agonists stimulated POMC neurons in the arcuate nucleus [258, 259]; and (c) 5HT2CR reactivation specifically in the POMC neurons of otherwise $5 H T 2 C R$-null mice improved energy homeostasis [260, 261]. Serotonin's effects on eating may involve several mechanisms: (a) direct activation of arcuate POMC neurons via 5HT2CR; (b) indirect 5HT1BR-mediated disinhibition of POMC neurons via blockade of local inhibitory inputs; and (c) direct inhibition of AgRP neurons [228, 256, 262]. Recent data demonstrate that 5HT2CR signaling in the POMC neurons is required to maintain energy homeostasis. Selective loss of $5 \mathrm{HT} 2 \mathrm{CR}$ signaling in POMC neurons resulted in hyperphagia and sensitization to diet-induced obesity and blunted the effects of d-fenfluramine and MCPP to suppress eating [263]. These data support the role of POMC neurons in the arcuate nucleus in the control of eating, in contrast to the demonstration that leptin receptor signaling via POMC neurons did not affect eating, but only energy expenditure [254, 264]. It is important to note that 5HT2CR and leptin receptors are expressed by anatomically and functionally distinct POMC neurons in the arcuate nucleus, but that these populations converge on similar second-order neurons, including those expressing MC4R [227, 228].

Finally, using an in vitro culture system of neurons expressing fluorophores under control of pomc transgenes that allowed electrophysiological characterization of identified neurons, Hentges and colleagues [265, 266] showed that there are many GABAergic and few glutamatergic subpopulations of POMC neurons. Consistent with GABA release, approximately $40 \%$ of POMC neurons express GABA-synthesizing enzymes GAD65 and GAD67 [265, 267]. Immunohistochemically, POMC axon terminals were readily identified as GABAergic or glutamatergic. To our knowledge, most of the evidence supporting a role of GABA receptors on POMC neurons on eating comes from one study in which mice that lacked metabotropic GABA receptors on POMC neurons were sound to be heavier than WT mice, but only when the mice were placed on high fat diet, and interestingly, it was more pronounced in males than in females [268].

\section{AgRP/NPY Neurons.}

The role of AgRP in the regulation of eating has been examined in a number of different rodent models. Some of the main findings are: (a) AgRP expression in the arcuate nucleus is increased during fasting and in mice with genetic leptin deficiency [247, 269, 270]; (b) Both overexpression of AgRP and intracerebroventricular AgRP administration increased eating [271, 272]; (c) 
Selective acute activation of AgRP neurons using DREADD pharmacogenetic technology [273] or optogenetic technology [216] induced voracious eating; (d) selective pharmacogenetic antagonism of AgRP neurons reduced eating [273]; (e) Interestingly, however, reduction of hypothalamic AgRP expression by RNA interference decreased body weight independent of changes in eating [274].

As with POMC neurons, leptin and insulin modulate of the activity of AgRP neurons. Deletion of leptin receptors on AgRP neurons increases body weight and adiposity [275]. When leptin receptors were deleted from both POMC and AgRP neurons, the mice became more obese, leading the authors to conclude that POMC and AgRP neurons work in a synergistically in response to leptin [275]. Insulin also acts on AgRP neurons in the arcuate nucleus [140, 188]. Unlike leptin, however, selective ablation of insulin receptors on AgRP neurons had no effect on body weight or food intake [188]. Several groups devised strategies to ablate AgRP neurons to determine the importance of these neurons in eating and body weight regulation [276-279]. Consistent with the data reviewed above, the results indicate that AgRP neurons are important for initiating meals and maintaining eating during meals in adult mice. Interestingly, however, adaptive mechanisms can compensate for the germ line AgRP lesions.

Two hypotheses have been proposed to account for AgRP's role in eating. First, AgRP exerts its action by blocking the binding of $\alpha-M S H$ to its receptor $[270,280-282]$. GABA release from AgRP neurons has a direct effect on POMC cells and probably on most post-synaptic MC4R-bearing cells [187, 283, 284]. GABA co-localizes with NPY-immuno-positive axon terminals that innervate local POMC neurons in both the arcuate and the paraventricular nuclei. Electrophysiological recordings indicate that leptin inhibits release of GABA from NPY terminals that synapse on POMC neurons [187]. Based on these observations, GABA output from AgRP neurons may be important to maintain a dynamic balance with excitatory signaling in certain post-synaptic target areas. Second, several lines of evidence suggest a melanocortin-independent pathway for AgRP. For example, AgRP still stimulated eating in MC4R KO mice [30]. In addition, chronic blockade of the melanocortin pathway in $A^{(y) / a}$ genetic background (in which agouti protein is ectopically expressed in the brain, thereby chronically blocking MC4R signaling) failed to ameliorate the severe anorexia after ablation of AgRP neurons [284].

The role of STAT3 in AgRP neurons has been examined in an attempt to identify the signaling mechanisms behind the role of AgRP neurons in the regulation of eating and body weight $[195,202,285]$. Data indicate: (a) STAT3 activation by leptin inhibited AgRP mRNA expression levels; (b) STAT3 deletion led to mild in body-weight gain in mice, but unlike the deletions of STAT3 in POMC neurons, the effects were due to changes in energy expenditure; (c) overexpression of STAT3 in AgRP neurons increased locomotor activity, with no changes in eating [195]. As mentioned in Section 4.2, the PI3K-PKD1-FoxO1 signaling pathway acts to integrate leptin and insulin signals. PI3K is required for 
the actions of leptin and insulin on AgRP neurons [197, 286, 287]. Deletion of PDK1 in AgRP neurons resulted in body weight loss as a consequence of decreased eating and enhanced energy expenditure [287]. Interestingly, in these same mice, leptin had an enhanced effect on eating. The specific deletion of FoxO1 in AgRP neurons was associated with decreased eating, without a change in body weight [200].

Although NPY and AgRP are secreted from the same arcuate neurons, unlike AgRP, NPY is also expressed in many other brain areas [288]. When administered into the cerebroventricular system or directly into the hypothalamus, exogenous NPY dose-dependently increases eating [289], and when it is administered chronically, body weight and body fat increase as well [289]. Whether injected into the hypothalamus [290-292] or the hindbrain [293-295], NPY elicits very short latency eating responses, typically seconds to minutes, and also prolongs eating once it has begun, with consequently larger meals being consumed. Thus, NPY both facilitates the onset of meals and delays satiation. Finally, the orexigenic response to NPY, like that to AgRP, is longlasting, often persisting for several hours or more [296-298].

There are data indicating that endogenous NPY also has an eatingstimulatory effect: (a) When antibodies to NPY were injected intraventricularly or directly into the VMH or PVN, food intake was decreased [299-301]; and (b) administration of NPY antisense oligonucleotides or adeno-associated virus to knock down endogenous NPY also inhibited eating [302, 303]. Further support for a role of endogenous NPY in eating comes from reports that fasting upregulated NPY mRNA in the ARC and NPY protein in the arcuate nculeus and paraventricular nucleus [304-307], and that these responses were reversed by refeeding [305, 308].

The dorsomedial hypothalamus is another site of NPY action. $\mathrm{Bi}$ and colleagues [309] tested the effects of AAV-mediated NPY overexpression in the dorsomedial nucleus. Rats increased food intake by increasing nocturnal meal size and increased body weight, and feeding a high-fat diet augmented these effects. $\mathrm{Bi}$ and colleagues also showed that OLETF rats, which lack $\mathrm{CCK}_{1}$ receptors and have elevated npy expression in the dorsomedial nucleus, NPY knockdown there completely normalized nocturnal meal size [295].

The neural circuits underlying the actions of arcuate and dorsomedial hypothalamus NPY seem to differ. Arcuate NPY serves as a downstream mediators of leptin's action on eating [310, 311], whereas dorsomedial NPY signaling is independent of leptin [312], but is affected by central (i.e., neurocrine, not endocrine) CCK signaling [313]. Hypothalamic NPY, however, may also be involved mediating endocrine CCK satiation because NPY administration in the $3^{\text {rd }}$ ventricle reduced the ability of intraperitoneal CCK to inhibit eating. This behavioral response was supported by the fact that NPY reduced c-Fos expression elicited by peripheral CCK, whereas NPY alone did not elicit any C- 
Fos expression by itself $[311,314]$. Since dorsomedial NPY neurons project to the NTS to modulate eating [295], these data suggest that both the dorsomedial hypothalamus and NTS are sites of action for the eating-stimulatory effects of NPY.

\section{Serotonin.}

Increasing (by administering a serotonin precursor) or decreasing (by lesioning) serotonin function has profound effects on eating [315]. Blundell [316] was the first to propose that the serotonergic system is involved in satiation. Indeed, serotonin function is now associated with both within-meal satiation and post-meal satiety [317]. Of the 14 subtypes of serotonin receptors now recognized, serotonin $2 \mathrm{C}$ and $1 \mathrm{~B}$ receptors ( $2 \mathrm{CR}$ and $1 \mathrm{BR}$, respectively) seem to mediate most of the effects of serotonergic drugs on eating behavior, apparently via increased $\alpha-\mathrm{MSH}$ release and reduced release $[256,262,318]$.

Transgenic mice that lacking serotonin 1BR exhibit increased body weight, which seemed to represent growth rather than obesity, and increased food intake that was in proportion to weight [319]. In another study, however, serotonin 1BR knockout mice displayed increased exploratory behavior but no change in food intake [320]. Serotonin 1BR agonists produce hypophagia, which is attenuated by $1 \mathrm{BR}$ antagonist treatment [321, 322]. Direct infusions of a serotonin 1BR agonist into the parabrachial nucleus of the pons, a serotonin target site, potently and selectively reduced eating [323]. The behavioral sequence of satiety was also preserved, with the onset of resting advanced [321].

The role of serotonin in the control of appetite was initially examined with the serotonin releaser and reuptake-inhibitor fenfluramine and its selective enantiomer $\mathrm{d}$-fenfluramine. Both drugs produced changes in eating behavior that were consistent with satiation, rather than hyperactivity and malaise [324-326]. The use of antagonists revealed that the effects of $d$-fenfluramine were mediated in part by 2CR receptors [327-329]. Selective serotonin 2CR agonists also increased satiation [330, 331]. Finally, mice lacking functional serotonin 2CR displayed marked hyperphagia, leading to the development of obesity [332, 333] and a normal behavioral sequence of satiety [328].

Pharmacological evidence indicates that peripheral CCK elicits satiation via brain serotonergic pathways involving serotonin 2CR [334-336]. The pharmacological tools used, however, were not highly selective to $2 \mathrm{CR}$ and were not administered locally, which is important because several populations of serotonin receptors in the brain and in the periphery have been implicated in CCK satiation. Studies in mice deficient in 2CR, however, showed that these serotonin receptors are crucial in the mediation of CCK satiation [337]. Furthermore, intraperitoneal injections of doses of GLP-1 that reduced eating in wild-type mice $50-60 \%$ had no reliable effect in 2CR knockout mice [337]. These are the first data that we know implicating serotonin in GLP-1 satiation. 
Several neuropeptides and neurotransmitters are involved in serotonin's effect on eating. mCPP, a 2CR/1BR agonist, activated POMC-and inhibited AgRP expressing neurons in the ARC $[256,259]$. The downstream modulation of the melanocortin system appears to be essential to the serotoninergic regulation of eating, since $A^{(y) / a}$ mice, mice treated with SHU9119 and Mc4r knockout mice were all insensitive to d-fenfluramine- and other serotonin receptor agonists that induced hypophagia [259, 262]. Selective expression of 2CR only on POMC neurons is sufficient to normalize the hyperphagia, obesity and to attenuate responses to anorectic serotonergic drugs in 5HT2CR knockout mice [260]. These data indicate that serotonin acting at the $2 \mathrm{CR}$ expressed on POMC neurons mediate much of serotonin's effects on eating and body weight.

NPY neurons receive serotonergic inputs [262, 338] and are hyperpolarized by 1BR agonists [262]. Levels of NPY mRNA and protein were decreased by pharmacological serotonin increase [339, 340]. Moreover, feeding induced by NPY administration was attenuated by d-fenfluramine [341, 342]. The inhibition of NPY/AgRP neurons by 1BR action, coupled with the activation of opposing POMC neurons by $2 \mathrm{CR}$ action, suggest that these receptors complement each other's effects on at least one convergent downstream pathway.

\section{Oxytocin.}

In 1989, Arletti and colleagues first demonstrated that intracerebroventricular oxytocin reduced eating and intracerebroventricular administration of an oxytocin receptor antagonist increased eating in rats [343]. Since then, many studies have linked changes in brain oxytocin signaling with changes in eating behavior: (1) hypothalamic oxytocin mRNA expression is reduced with fasting and restored upon refeeding; (2) eating activated oxytocin neurons in rats; and (3) reduction of oxytocin mRNA and protein the paraventricular nucleus led mice to develop obesity, which can be rescued by oxytocin treatment $[344,345]$.

The mechanisms underlying the effects of oxytocin on eating are not well understood. Studies in rodents indicate that oxytocin decreases eating primarily by decreasing meal size, and that hindbrain signaling is involved. Administration of an oxytocin antagonist alone stimulates eating [168, 343, 346-348], by increasing meal size [349]. Functional and anatomical data provide evidence for an interaction between oxytocin and hindbrain signaling mediating meal size.

Mice lacking oxytocin or oxytocin receptors develop late-onset obesity with little changes in daily food intake [350-352], and pair-feeding studies confirm that reductions in eating only partially account for oxytocin's effect on body weight, suggesting that oxytocin also controls energy expenditure [353, 354]. 


\section{Noradrenergic neurons.}

Neurons in the caudal brainstem noradrenergic A2 cell group are reciprocally connected with several brain regions. Direct projections from the cortex, limbic forebrain and hypothalamus to the A2 cell group modulate a variety of visceral responses [355]. In turn ascending projections from A2 neurons provide a route through which feedback from the viscera affects not only hypothalamic function, but also emotional and cognitive processing [355, 356].

Different subpopulations of A2 neurons are recruited by signals that increase or decrease eating, perhaps because different subpopulations target different brain regions, and/or because different combinations of adrenergic receptors are expressed in those regions [357]. A2 neurons seem to be activated in every experimental situation in which food intake is inhibited, including normal satiety [358-363]. A2 neurons are recruited in a graded manner in rats after eating, such that larger meals activate larger numbers of A2 neurons [364]. A2 neurons are also necessary for the satiating effect of CCK $[350,365,366]$.

\section{Forebrain-hindbrain neural networks for satiation.}

Satiation in the decerebrate rat. The general plan of a neural system for the control of the basic, rhythmic movements of eating consists of two categories of neurons: first, a network of neurons that generate the rhythmic motor output, referred to as a central pattern generator (CPG), and, second, all of the inputs to the CPG that turn it on and off. The CPG for licking, masticating, swallowing and other eating movements are in the hindbrain. These are normally controlled by local afferent stimuli that project to the hindbrain from the mouth, GI tract, etc., and by descending inputs from the forebrain stimuli carrying information about the current environment, metabolic state, the effects of prior ingestive experience, mood, ongoing brain activities not directly related to eating, etc. Disconnecting the caudal brainstem from the forebrain, thus, should reveal the capacity of afferent stimuli that project to the caudal brainstem below the level of the disconnection to control the CPG in the absence of forebrain afferent stimuli. Grill and colleagues have accomplished this analysis by investigating the control of liquid intake in the chronic decerebrate rat [367].

The decerebrate rat, even when food deprived, does not initiate eating despite the presence of food in its environment. If liquid food is infused into the mouth through a chronically implanted oral catheter, however, the decerebrate rat initiates eating. It continues for a time and then stops, allowing the infused liquid to drain out of its mouth; importantly, it does not emit mouth movements indicative of aversion, such as when bitter food is infused. Furthermore, after eating it grooms and then is quiescent. Thus, like an intact rat, the decerebrate rat eats meals. In addition, the size of these meals is sensitive to feedback control; for example, decerebrate rats eat more of sweeter food and eat less after CCK injection. With regard to metabolic sensing, the picture is more complicated 
- decerebrate rats eat more in response to 2-deoxy-d-glucose, which blocks glucose metabolism, but not in response to mercaptoacetate, which blocks fattyacid oxidation. They also fail to respond to food deprivation [368]. These results demonstrate that (a) the disconnected caudal brainstem has sufficient capacity to integrate a variety of positive and negative feedbacks and to appropriately control the CPG for eating so as to produce a near-normal meal, and (b) a variety of controls of eating and satiation depend critically on the forebrain. The next sections consider, first, some evidence concerning neural basis of the integrative capacity of the caudal brainstem and, second, how forebrain controls reach the caudal brainstem, research that represent the beginning of constructing a complete neural network for satiation.

Caudal brainstem integrative networks. DVC POMC neurons are involved in the control of eating by CCK. In a series of experiments, Fan and colleagues (2004) showed that CCK activates NTS POMC-EGFP neurons and that CCK treatment fails to elicit satiation in MC4R KO mice. Berthoud et al. [369] found that hyperphagia induced by the MC4R antagonist SHU-9119 injected into the $4^{\text {th }}$ ventricle was characterized by increases in meal size, with no effect on meal frequency (see also [370]). The same results were reported following $4^{\text {th }}$ ventricular injections of MTII. A suggested mechanism for the interaction of the melanocortin and CCK signaling systems comes from studies revealing that MC4R are expressed on presynaptically on vagal afferents and postsynaptically on NTS neurons themselves [371]. Since the neurons stimulated with MTII responded with an increase in EPSC frequency, the authors concluded that MC4R signaling involves presynaptic enhancement of glutamate synaptic transmission, and suggested that it is this mechanism, rather than postsynaptic activation of NTS neurons, that may account for the melanocortinergic-induced decreases in eating via enhancement of vagal afferent satiation signals from the GI tract.

Brainstem leptin signaling seems to be act by modulating CCK satiation. This is because Hayes et al. [372], using an RNA interference method, found that selective knock-down of Leprb in the NTS increased food intake and body weight and decreased CCK satiation. There is a very similar interaction between leptin and GLP-1 satiation signaling also in the NTS [373].

Finally, $4^{\text {th }}$ ventricle injections of $d$-fenfluramine and serotonin receptor agonists reduced eating in decerebrate rats, suggesting that serotonin action in the caudal brainstem is sufficient to provide some level of control over food intake $[374,375]$.

Descending projections for satiation. Several lines of research indicate that forebrain eating-control signals do not project directly to caudal brainstem CPG, but rather project to circuits that integrate GI satiation mechanisms. Perhaps the first evidence for this were reports that insulin and leptin increased the satiating potency of peripheral CCK in a dose-depended fashion [376]. These latter 
investigators then localized the leptin/CCK interaction at least in part to the NTS by demonstrating that leptin also increased the potencies of both CCK [377] and intragastric nutrient loads [377] to activate neurons in the NTS, as indicated by CFos immunochemistry.

Morton and colleagues [378] elegantly extended these earlier findings using Koletsky rats, which bear a global Leprb defect. They demonstrated that (a) these rats have increased meal size, a decreased satiation response to exogenous CCK, and reduced c-Fos expression in the NTS after CCK injection; and (b) transgenic replacement of Leprb specifically in the arcuate nucleus normalized all three defects. The same investigators [370] went on to identify the forebrain-brainstem projection that is likely to be involved in this interaction by showing: (a) injection of an MC4R antagonist into the paraventricular nucleus reduced CCK satiation, and (b) PVN neurons that were labeled after injection of a retrograde neuronal tracer into the NTS and collected by laser-capture microdissection express MC4R.

Oxytocinergic projections from the hypothalamus to the caudal brainstem are also involved in the control of eating. Oxytocin projections comprise $\sim 6 \%$ of all paraventricular nucleus projections to the DVC and provide its sole source of oxytocin [360, 379, 380]. Release of oxytocin from descending paraventricular nucleus-NTS projections enhanced visceral afferent transmission to the NTS [381]. Kirchgessner and her colleagues [382] provided the initial suggestion that this projection is involved in eating by showing that knife cuts that sever the paraventricular nucleus-hindbrain oxytocin projections resulted in hyperphagia and obesity. More recently, Blevins et al. [383, 384] confirmed this and also showed that reductions in hindbrain oxytocin signaling reduce the satiating potency of CCK in rats. Leptin also seems to affect this oxytocin signaling: (1) leptin activated paraventricular nucleus oxytocin neurons and increased the expression of oxytocin mRNA in paraventricular nucleus, probably via melanocortin-dependent mechanisms [344, 349, 385, 386], and (2) $3^{\text {rd }}$ ventricular administration of oxytocin antagonists blunted leptin's anorectic effects and abolished its ability to enhance CCK activation of the NTS [349], as well as reversing the anorectic effect of $\alpha-\mathrm{MSH}$ [387].

\section{Conclusions.}

We have reviewed the basic physiology of satiation. Eating contributes to the regulation of energy homeostasis via control of satiation. GI nutrient sensing generates negative feedback signals encoded as concentrations of the peptides CCK, GLP-1 and PYY (3-36) secreted during meals. There is substantial evidence that each of these contributes to the normal physiological control of satiation. Metabolic-sensing neurons located mainly in the hypothalamus and caudal brainstem react to circulating levels of glucose, FFA, leucine, leptin and insulin to generate signals that may also contribute to satiation, but the physiological status of most of these is not yet firmly established. A number of 
neurotransmitters are involved in the processing of these signals into satiation. A main feature of this processing is that information derived from metabolic-sensing neurons converges on the caudal brainstem interneuronal networks that process information derived from GI nutrient-sensing rather than projecting directly onto the motor neural networks that finally control eating. Progress in understanding these control of satiation should provide a platform for future research addressing the physiologies of the myriad other controls of satiation, such as food reward, cognitive, and social controls. Furthermore, better understanding of the operation of this satiation system described here should suggest opportunities for novel peripheral and brain manipulations that may improve therapies for overeating and obesity and the many diseases that they lead to.

\section{Acknowledgements}


The authors thank Prof. Nori Geary for helpful discussions on the penultimate draft. We are supported by NIH NIDDK 092608 (LA).

\section{References}


1) Leibel RL. Molecular physiology of weight regulation in mice and humans. International journal of obesity 2008; 32 Suppl 7: S98-108.

2) Geary N, Grotschel H, Petry HP, Scharrer E. Meal patterns and body weight changes during insulin hyperphagia and postinsulin hypophagia. Behavioral and neural biology 1981; 31: 435-42.

3) Geary N, Grotschel H, Scharrer E. Blood metabolites and feeding during postinsulin hypophagia. The American journal of physiology 1982; 243: R304-11.

4) Davies RF. Long-and short-term regulation of feeding patterns in the rat. Journal of comparative and physiological psychology 1977; 91: 574-85.

5) Strubbe JH, van Dijk G. The temporal organization of ingestive behaviour and its interaction with regulation of energy balance. Neuroscience and biobehavioral reviews 2002; 26: 485-98.

6) Leung PM, Horwitz BA. Free-feeding patterns of rats in response to changes in environmental temperature. The American journal of physiology 1976; 231: $1220-4$.

7) Vanderweele DA. Insulin and satiety from feeding in pancreatic-normal and diabetic rats. Physiology \& behavior 1993; 54: 477-85.

8) Thomas DW, Scharrer E, Mayer J. Effects of alloxan induced diabetes on the feeding patterns of rats. Physiology \& behavior 1976; 17: 345-9.

9) Strubbe JH, Gorissen J. Meal patterning in the lactating rat. Physiology \& behavior 1980; 25: 775-7.

10) Eckel LA, Houpt TA, Geary N. Spontaneous meal patterns in female rats with and without access to running wheels. Physiology \& behavior 2000; 70: 397405.

11) Enns MP, Grinker JA. Dietary self-selection and meal patterns of obese and lean Zucker rats. Appetite 1983; 4: 281-93.

12) Castonguay TW, Upton DE, Leung PM, Stern JS. Meal patterns in the genetically obese Zucker rat: a reexamination. Physiology \& behavior 1982; 28: 911-6.

13) Eckel LA, Langhans W, Kahler A, Campfield LA, Smith FJ, Geary N. Chronic administration of $\mathrm{OB}$ protein decreases food intake by selectively reducing meal size in female rats. The American journal of physiology 1998; 275: R186-93. 
14) Kahler A, Geary N, Eckel LA, Campfield LA, Smith FJ, Langhans W. Chronic administration of $\mathrm{OB}$ protein decreases food intake by selectively reducing meal size in male rats. The American journal of physiology 1998; 275: R1805 .

15) Levitsky DA. Feeding patterns of rats in response to fasts and changes in environmental conditions. Physiology \& behavior 1970; 5: 291-300.

16) Del Prete E, Balkowski G, Scharrer E. Meal pattern of rats during hyperphagia induced by longterm food restriction is affected by diet composition. Appetite 1994; 23: 79-86.

17) Penicaud L, Le Magnen J. Recovery of body weight following starvation or food restriction in rats. Neuroscience and biobehavioral reviews 1980; 4 Suppl 1: 47-52.

18) West DB, Greenwood MR, Marshall KA, Woods SC. Lithium chloride, cholecystokinin and meal patterns: evidence that cholecystokinin suppresses meal size in rats without causing malaise. Appetite 1987; 8: 221-7.

19) Girardet C, Bonnet MS, Jdir R, Sadoud M, Thirion S, Tardivel C, Roux J, Lebrun B, Wanaverbecq N, Mounien L, Trouslard J, Jean A, Dallaporta M, Troadec JD. The food-contaminant deoxynivalenol modifies eating by targeting anorexigenic neurocircuitry. PloS one 2011; 6: e26134.

20) Flannery BM, Clark ES, Pestka JJ. Anorexia induction by the trichothecene deoxynivalenol (vomitoxin) is mediated by the release of the gut satiety hormone peptide YY. Toxicological sciences : an official journal of the Society of Toxicology 2012; 130: 289-97.

21) Varma M, Chai JK, Meguid MM, Yang ZJ. Gender differences in tumor-induced anorectic feeding pattern in Fischer-344 rats. Physiology \& behavior 2001; 74: 29-35.

22) Smith GP. The controls of eating: a shift from nutritional homeostasis to behavioral neuroscience. Nutrition 2000; 16: 814-20.

23) Levin BE, Magnan C, Dunn-Meynell A, Le Foll C. Metabolic sensing and the brain: who, what, where, and how? Endocrinology 2011; 152: 2552-7.

24) Le Foll C, Dunn-Meynell AA, Miziorko HM, Levin BE. Regulation of Hypothalamic Neuronal Sensing and Food Intake By Ketone Bodies and Fatty Acids. Diabetes 2013; 
25) Tabarin A, Diz-Chaves Y, Consoli D, Monsaingeon M, Bale TL, Culler MD, Datta R, Drago F, Vale WW, Koob GF, Zorrilla EP, Contarino A. Role of the corticotropin-releasing factor receptor type 2 in the control of food intake in mice: a meal pattern analysis. The European journal of neuroscience 2007; 26: 2303-14.

26) Cohen DA. Neurophysiological pathways to obesity: below awareness and beyond individual control. Diabetes 2008; 57: 1768-73.

27) Farley C, Cook JA, Spar BD, Austin TM, Kowalski TJ. Meal pattern analysis of diet-induced obesity in susceptible and resistant rats. Obesity research 2003; 11: 845-51.

28) Hariri N, Thibault L. Dietary obesity caused by a specific circadian eating pattern. Chronobiology international 2011; 28: 216-28.

29) Wang L, Stengel A, Goebel M, Martinez V, Gourcerol G, Rivier J, Tache Y. Peripheral activation of corticotropin-releasing factor receptor 2 inhibits food intake and alters meal structures in mice. Peptides 2011; 32: 51-9.

30) Fekete C, Legradi G, Mihaly E, Huang QH, Tatro JB, Rand WM, Emerson CH, Lechan RM. alpha-Melanocyte-stimulating hormone is contained in nerve terminals innervating thyrotropin-releasing hormone-synthesizing neurons in the hypothalamic paraventricular nucleus and prevents fasting-induced suppression of prothyrotropin-releasing hormone gene expression. The Journal of neuroscience : the official journal of the Society for Neuroscience 2000; 20: 1550-8.

31) Asarian L, Geary N. Sex differences in the physiology of eating. American journal of physiology. Regulatory, integrative and comparative physiology 2013; 305: R1215-67.

32) Davis JD, Smith GP. Learning to sham feed: behavioral adjustments to loss of physiological postingestional stimuli. The American journal of physiology 1990; 259: R1228-35.

33) Sclafani A, Ackroff K. Role of gut nutrient sensing in stimulating appetite and conditioning food preferences. American journal of physiology. Regulatory, integrative and comparative physiology 2012; 302: R1119-33.

34) Johnson AW. Eating beyond metabolic need: how environmental cues influence feeding behavior. Trends in neurosciences 2013; 36: 101-9.

35) Booth DA. Satiety and appetite are conditioned reactions. Psychosomatic medicine 1977; 39: 76-81. 
36) Birch LL, Doub AE. Learning to eat: birth to age $2 \mathrm{y}$. The American journal of clinical nutrition 2014;

37) Hwang ES, Hirayama BA, Wright EM. Distribution of the SGLT1 Na+/glucose cotransporter and mRNA along the crypt-villus axis of rabbit small intestine. Biochemical and biophysical research communications 1991; 181: 1208-17.

38) Yoshida A, Takata K, Kasahara $T$, Aoyagi $T$, Saito $S$, Hirano $H$. Immunohistochemical localization of $\mathrm{Na}(+)$-dependent glucose transporter in the rat digestive tract. The Histochemical journal 1995; 27: 420-6.

39) Balakrishnan A, Stearns AT, Rounds J, Irani J, Giuffrida M, Rhoads DB, Ashley SW, Tavakkolizadeh A. Diurnal rhythmicity in glucose uptake is mediated by temporal periodicity in the expression of the sodium-glucose cotransporter (SGLT1). Surgery 2008; 143: 813-8.

40) Stearns AT, Balakrishnan A, Rhoads DB, Tavakkolizadeh A. Rapid upregulation of sodium-glucose transporter SGLT1 in response to intestinal sweet taste stimulation. Annals of surgery 2010; 251: 865-71.

41) Ritzel U, Fromme A, Ottleben M, Leonhardt U, Ramadori G. Release of glucagon-like peptide-1 (GLP-1) by carbohydrates in the perfused rat ileum. Acta diabetologica 1997; 34: 18-21.

42) Sykes S, Morgan LM, English J, Marks V. Evidence for preferential stimulation of gastric inhibitory polypeptide secretion in the rat by actively transported carbohydrates and their analogues. The Journal of endocrinology 1980; 85: 201-7.

43) Parker HE, Habib AM, Rogers GJ, Gribble FM, Reimann F. Nutrient-dependent secretion of glucose-dependent insulinotropic polypeptide from primary murine K cells. Diabetologia 2009; 52: 289-98.

44) Reimann F, Habib AM, Tolhurst G, Parker HE, Rogers GJ, Gribble FM. Glucose sensing in L cells: a primary cell study. Cell metabolism 2008; 8: 532-9.

45) Yoshikawa $T$, Inoue $R$, Matsumoto $M$, Yajima $T$, Ushida $K$, Iwanaga $T$. Comparative expression of hexose transporters (SGLT1, GLUT1, GLUT2 and GLUT5) throughout the mouse gastrointestinal tract. Histochemistry and cell biology 2011; 135: 183-94.

46) Freeman SL, Glatzle J, Robin CS, Valdellon M, Sternini C, Sharp JW, Raybould HE. Ligand-induced 5-HT3 receptor internalization in enteric neurons in rat ileum. Gastroenterology 2006; 131: 97-107. 
47) Zhu JX, Zhu XY, Owyang C, Li Y. Intestinal serotonin acts as a paracrine substance to mediate vagal signal transmission evoked by luminal factors in the rat. The Journal of physiology 2001; 530: 431-42.

48) Vincent KM, Sharp JW, Raybould HE. Intestinal glucose-induced calciumcalmodulin kinase signaling in the gut-brain axis in awake rats. Neurogastroenterology and motility : the official journal of the European Gastrointestinal Motility Society 2011; 23: e282-93.

49) El-Ouaghlidi A, Rehring E, Holst JJ, Schweizer A, Foley J, Holmes D, Nauck MA. The dipeptidyl peptidase 4 inhibitor vildagliptin does not accentuate glibenclamide-induced hypoglycemia but reduces glucose-induced glucagonlike peptide 1 and gastric inhibitory polypeptide secretion. The Journal of clinical endocrinology and metabolism 2007; 92: 4165-71.

50) Jang HJ, Kokrashvili Z, Theodorakis MJ, Carlson OD, Kim BJ, Zhou J, Kim HH, Xu X, Chan SL, Juhaszova M, Bernier M, Mosinger B, Margolskee RF, Egan JM. Gut-expressed gustducin and taste receptors regulate secretion of glucagonlike peptide-1. Proceedings of the National Academy of Sciences of the United States of America 2007; 104: 15069-74.

51) Gerspach AC, Steinert RE, Schonenberger L, Graber-Maier A, Beglinger C. The role of the gut sweet taste receptor in regulating GLP-1, PYY, and CCK release in humans. American journal of physiology. Endocrinology and metabolism 2011; 301: E317-25.

52) Steinert RE, Gerspach AC, Gutmann H, Asarian L, Drewe J, Beglinger C. The functional involvement of gut-expressed sweet taste receptors in glucosestimulated secretion of glucagon-like peptide-1 (GLP-1) and peptide YY (PYY). Clinical nutrition 2011; 30: 524-32.

53) Mace OJ, Affleck J, Patel N, Kellett GL. Sweet taste receptors in rat small intestine stimulate glucose absorption through apical GLUT2. The Journal of physiology 2007; 582: 379-92.

54) Meyer JH, Hlinka M, Khatibi A, Raybould HE, Tso P. Role of small intestine in caloric compensations to oil premeals in rats. The American journal of physiology 1998; 275: R1320-33.

55) McLaughlin JT, Lomax RB, Hall L, Dockray GJ, Thompson DG, Warhurst G. Fatty acids stimulate cholecystokinin secretion via an acyl chain lengthspecific, Ca2+-dependent mechanism in the enteroendocrine cell line STC-1. The Journal of physiology 1998; 513 ( Pt 1): 11-8. 
56) Raybould HE, Meyer JH, Tabrizi Y, Liddle RA, Tso P. Inhibition of gastric emptying in response to intestinal lipid is dependent on chylomicron formation. The American journal of physiology 1998; 274: R1834-8.

57) Briscoe CP, Tadayyon M, Andrews JL, Benson WG, Chambers JK, Eilert MM, Ellis C, Elshourbagy NA, Goetz AS, Minnick DT, Murdock PR, Sauls HR, Jr., Shabon U, Spinage LD, Strum JC, Szekeres PG, Tan KB, Way JM, Ignar DM, Wilson S, Muir AI. The orphan G protein-coupled receptor GPR40 is activated by medium and long chain fatty acids. The Journal of biological chemistry 2003; 278: 11303-11.

58) Brown AJ, Goldsworthy SM, Barnes AA, Eilert MM, Tcheang L, Daniels D, Muir AI, Wigglesworth MJ, Kinghorn I, Fraser NJ, Pike NB, Strum JC, Steplewski KM, Murdock PR, Holder JC, Marshall FH, Szekeres PG, Wilson S, Ignar DM, Foord SM, Wise A, Dowell SJ. The Orphan G protein-coupled receptors GPR41 and GPR43 are activated by propionate and other short chain carboxylic acids. The Journal of biological chemistry 2003; 278: 11312-9.

59) Hirasawa A, Tsumaya K, Awaji T, Katsuma S, Adachi T, Yamada M, Sugimoto Y, Miyazaki S, Tsujimoto G. Free fatty acids regulate gut incretin glucagon-like peptide-1 secretion through GPR120. Nature medicine 2005; 11: 90-4.

60) Nilsson NE, Kotarsky K, Owman C, Olde B. Identification of a free fatty acid receptor, FFA2R, expressed on leukocytes and activated by short-chain fatty acids. Biochemical and biophysical research communications 2003; 303: 1047-52.

61) Liou AP, Lu X, Sei Y, Zhao X, Pechhold S, Carrero RJ, Raybould HE, Wank S. The G-protein-coupled receptor GPR40 directly mediates long-chain fatty acid-induced secretion of cholecystokinin. Gastroenterology 2011; 140: 90312.

62) Edfalk S, Steneberg P, Edlund H. Gpr40 is expressed in enteroendocrine cells and mediates free fatty acid stimulation of incretin secretion. Diabetes 2008; 57: 2280-7.

63) Liou AP, Sei Y, Zhao X, Feng J, Lu X, Thomas C, Pechhold S, Raybould HE, Wank SA. The extracellular calcium-sensing receptor is required for cholecystokinin secretion in response to L-phenylalanine in acutely isolated intestinal I cells. American journal of physiology. Gastrointestinal and liver physiology 2011; 300: G538-46.

64) Tanaka T, Katsuma S, Adachi T, Koshimizu TA, Hirasawa A, Tsujimoto G. Free fatty acids induce cholecystokinin secretion through GPR120. NaunynSchmiedeberg's archives of pharmacology 2008; 377: 523-7. 
65) Overton HA, Babbs AJ, Doel SM, Fyfe MC, Gardner LS, Griffin G, Jackson HC, Procter MJ, Rasamison CM, Tang-Christensen M, Widdowson PS, Williams GM, Reynet C. Deorphanization of a G protein-coupled receptor for oleoylethanolamide and its use in the discovery of small-molecule hypophagic agents. Cell metabolism 2006; 3: 167-75.

66) Chu ZL, Carroll C, Alfonso J, Gutierrez V, He H, Lucman A, Pedraza M, Mondala $\mathrm{H}$, Gao H, Bagnol D, Chen R, Jones RM, Behan DP, Leonard J. A role for intestinal endocrine cell-expressed g protein-coupled receptor 119 in glycemic control by enhancing glucagon-like Peptide-1 and glucosedependent insulinotropic Peptide release. Endocrinology 2008; 149: 203847.

67) Lan H, Vassileva G, Corona A, Liu L, Baker H, Golovko A, Abbondanzo SJ, Hu W, Yang S, Ning Y, Del Vecchio RA, Poulet F, Laverty M, Gustafson EL, Hedrick JA, Kowalski TJ. GPR119 is required for physiological regulation of glucagonlike peptide-1 secretion but not for metabolic homeostasis. The Journal of endocrinology 2009; 201: 219-30.

68) Fukuwatari $T$, Kawada $T$, Tsuruta M, Hiraoka $T$, Iwanaga $T$, Sugimoto $E$, Fushiki T. Expression of the putative membrane fatty acid transporter (FAT) in taste buds of the circumvallate papillae in rats. FEBS letters 1997; 414: 461-4.

69) Khan NA, Besnard P. Oro-sensory perception of dietary lipids: new insights into the fat taste transduction. Biochimica et biophysica acta 2009; 1791: 149-55.

70) Sclafani A, Ackroff K, Abumrad NA. CD36 gene deletion reduces fat preference and intake but not post-oral fat conditioning in mice. American journal of physiology. Regulatory, integrative and comparative physiology 2007; 293: R1823-32.

71) Simons PJ, Boon L. Lingual CD36 and obesity: a matter of fat taste? Acta histochemica 2011; 113: 765-7; author reply 68-9.

72) Martin C, Chevrot M, Poirier H, Passilly-Degrace P, Niot I, Besnard P. CD36 as a lipid sensor. Physiology \& behavior 2011; 105: 36-42.

73) Schwartz GJ, Fu J, Astarita G, Li X, Gaetani S, Campolongo P, Cuomo V, Piomelli D. The lipid messenger OEA links dietary fat intake to satiety. Cell metabolism 2008; 8: 281-8.

74) Fu J, Gaetani S, Oveisi F, Lo Verme J, Serrano A, Rodriguez De Fonseca F, Rosengarth A, Luecke H, Di Giacomo B, Tarzia G, Piomelli D. 
Oleylethanolamide regulates feeding and body weight through activation of the nuclear receptor PPAR-alpha. Nature 2003; 425: 90-3.

75) Nemoz-Gaillard E, Bernard C, Abello J, Cordier-Bussat M, Chayvialle JA, Cuber JC. Regulation of cholecystokinin secretion by peptones and peptidomimetic antibiotics in STC-1 cells. Endocrinology 1998; 139: 932-8.

76) Choi S, Lee M, Shiu AL, Yo SJ, Hallden G, Aponte GW. GPR93 activation by protein hydrolysate induces CCK transcription and secretion in STC- 1 cells. American journal of physiology. Gastrointestinal and liver physiology 2007; 292: G1366-75.

77) Kotarsky K, Boketoft A, Bristulf J, Nilsson NE, Norberg A, Hansson S, Owman C, Sillard R, Leeb-Lundberg LM, Olde B. Lysophosphatidic acid binds to and activates GPR92, a G protein-coupled receptor highly expressed in gastrointestinal lymphocytes. The Journal of pharmacology and experimental therapeutics 2006; 318: 619-28.

78) Lee CW, Rivera R, Gardell S, Dubin AE, Chun J. GPR92 as a new G12/13- and Gq-coupled lysophosphatidic acid receptor that increases cAMP, LPA5. The Journal of biological chemistry 2006; 281: 23589-97.

79) Nelson G, Chandrashekar J, Hoon MA, Feng L, Zhao G, Ryba NJ, Zuker CS. An amino-acid taste receptor. Nature 2002; 416: 199-202.

80) Li X, Staszewski L, Xu H, Durick K, Zoller M, Adler E. Human receptors for sweet and umami taste. Proceedings of the National Academy of Sciences of the United States of America 2002; 99: 4692-6.

81) Bezencon C, le Coutre J, Damak S. Taste-signaling proteins are coexpressed in solitary intestinal epithelial cells. Chemical senses 2007; 32: 41-9.

82) Rey O, Young SH, Jacamo R, Moyer MP, Rozengurt E. Extracellular calcium sensing receptor stimulation in human colonic epithelial cells induces intracellular calcium oscillations and proliferation inhibition. Journal of cellular physiology 2010; 225: 73-83.

83) Wang Y, Chandra R, Samsa LA, Gooch B, Fee BE, Cook JM, Vigna SR, Grant AO, Liddle RA. Amino acids stimulate cholecystokinin release through the Ca2+sensing receptor. American journal of physiology. Gastrointestinal and liver physiology 2011; 300: G528-37.

84) Gibbs J, Young RC, Smith GP. Cholecystokinin decreases food intake in rats. Journal of comparative and physiological psychology 1973; 84: 488-95. 
85) Lieverse RJ, van Seters AP, Jansen JB, Lamers CB. Relationship between hunger and plasma cholecystokinin during weight reduction with a very low calorie diet. International journal of obesity and related metabolic disorders : journal of the International Association for the Study of Obesity 1993; 17: 177-9.

86) Reidelberger RD, Solomon TE. Comparative effects of CCK-8 on feeding, sham feeding, and exocrine pancreatic secretion in rats. The American journal of physiology 1986; 251: R97-105.

87) Reidelberger RD, Varga G, Liehr RM, Castellanos DA, Rosenquist GL, Wong HC, Walsh JH. Cholecystokinin suppresses food intake by a nonendocrine mechanism in rats. The American journal of physiology 1994; 267: R901-8.

88) Greenberg D, Smith GP, Gibbs J. Infusion of CCK-8 into hepatic-portal vein fails to reduce food intake in rats. The American journal of physiology 1987; 252: R1015-8.

89) Strubbe JH, Wolsink JG, Schutte AM, Balkan B, Prins AJ. Hepatic-portal and cardiac infusion of CCK-8 and glucagon induce different effects on feeding. Physiology \& behavior 1989; 46: 643-6.

90) Greenberg D, Smith GP. Hepatic-portal infusion reduces the satiating potency of CCK-8. Physiology \& behavior 1988; 44: 535-8.

91) Cox JE, Kelm GR, Meller ST, Randich A. Suppression of food intake by GI fatty acid infusions: roles of celiac vagal afferents and cholecystokinin. Physiology \& behavior 2004; 82: 27-33.

92) Kissileff HR, Thornton JC, Torres MI, Pavlovich K, Mayer LS, Kalari V, Leibel RL, Rosenbaum M. Leptin reverses declines in satiation in weight-reduced obese humans. The American journal of clinical nutrition 2012; 95: 309-17.

93) Ballinger AB, Clark ML. L-phenylalanine releases cholecystokinin (CCK) and is associated with reduced food intake in humans: evidence for a physiological role of CCK in control of eating. Metabolism: clinical and experimental 1994; 43: 735-8.

94) Matzinger D, Degen L, Drewe J, Meuli J, Duebendorfer R, Ruckstuhl N, D'Amato M, Rovati L, Beglinger C. The role of long chain fatty acids in regulating food intake and cholecystokinin release in humans. Gut 2000; 46: 688-93.

95) Beglinger C, Degen L, Matzinger D, D'Amato M, Drewe J. Loxiglumide, a CCK-A receptor antagonist, stimulates calorie intake and hunger feelings in humans. 
American journal of physiology. Regulatory, integrative and comparative physiology 2001; 280: R1149-54.

96) Melville LD, Smith GP, Gibbs J. Devazepide antagonizes the inhibitory effect of cholecystokinin on intake in sham-feeding rats. Pharmacol Biochem Behav 1992; 43: 975-7.

97) Reidelberger RD, O'Rourke MF. Potent cholecystokinin antagonist L 364718 stimulates food intake in rats. The American journal of physiology 1989; 257: R1512-8.

98) Reidelberger RD, Varga G, Solomon TE. Effects of selective cholecystokinin antagonists L364,718 and L365,260 on food intake in rats. Peptides 1991; 12: 1215-21.

99) Dourish CT, Ruckert AC, Tattersall FD, Iversen SD. Evidence that decreased feeding induced by systemic injection of cholecystokinin is mediated by CCKA receptors. European journal of pharmacology 1989; 173: 233-4.

100) Moran TH, Ameglio PJ, Schwartz GJ, McHugh PR. Blockade of type A, not type $B$, CCK receptors attenuates satiety actions of exogenous and endogenous CCK. The American journal of physiology 1992; 262: R46-50.

101) Funakoshi A, Miyasaka K, Shinozaki H, Masuda M, Kawanami T, Takata $Y$, Kono A. An animal model of congenital defect of gene expression of cholecystokinin (CCK)-A receptor. Biochemical and biophysical research communications 1995; 210: 787-96.

102) Takiguchi S, Takata Y, Funakoshi A, Miyasaka K, Kataoka K, Fujimura $Y$, Goto T, Kono A. Disrupted cholecystokinin type-A receptor (CCKAR) gene in OLETF rats. Gene 1997; 197: 169-75.

103) Moran TH, Katz LF, Plata-Salaman CR, Schwartz GJ. Disordered food intake and obesity in rats lacking cholecystokinin A receptors. The American journal of physiology 1998; 274: R618-25.

104) Schwartz GJ, Whitney A, Skoglund C, Castonguay TW, Moran TH. Decreased responsiveness to dietary fat in Otsuka Long-Evans Tokushima fatty rats lacking CCK-A receptors. The American journal of physiology 1999; 277: R1144-51.

105) Antin J, Gibbs J, Smith GP. Cholecystokinin interacts with pregastric food stimulation to elicit satiety in the rat. Physiology \& behavior 1978; 20: 67-70. 
106) Schwartz GJ, McHugh PR, Moran TH. Gastric loads and cholecystokinin synergistically stimulate rat gastric vagal afferents. The American journal of physiology 1993; 265: R872-6.

107) Peters JH, Ritter RC, Simasko SM. Leptin and CCK selectively activate vagal afferent neurons innervating the stomach and duodenum. American journal of physiology. Regulatory, integrative and comparative physiology 2006; 290: R1544-9.

108) Hayes MR, Covasa M. CCK and 5-HT act synergistically to suppress food intake through simultaneous activation of CCK-1 and 5-HT3 receptors. Peptides 2005; 26: 2322-30.

109) Savastano DM, Covasa M. Intestinal nutrients elicit satiation through concomitant activation of CCK(1) and 5-HT(3) receptors. Physiology \& behavior 2007; 92: 434-42.

110) Lo CM, Zhang DM, Pearson K, Ma L, Sun W, Sakai RR, Davidson WS, Liu M, Raybould HE, Woods SC, Tso P. Interaction of apolipoprotein AIV with cholecystokinin on the control of food intake. American journal of physiology. Regulatory, integrative and comparative physiology 2007; 293: R1490-4.

111) Le Sauter J, Geary N. Pancreatic glucagon and cholecystokinin synergistically inhibit sham feeding in rats. The American journal of physiology 1987; 253: R719-25.

112) Mollet A, Meier S, Grabler V, Gilg S, Scharrer E, Lutz TA. Endogenous amylin contributes to the anorectic effects of cholecystokinin and bombesin. Peptides 2003; 24: 91-8.

113) de Lartigue G, Dimaline R, Varro A, Dockray GJ. Cocaine- and amphetamineregulated transcript: stimulation of expression in rat vagal afferent neurons by cholecystokinin and suppression by ghrelin. The Journal of neuroscience : the official journal of the Society for Neuroscience 2007; 27: 2876-82.

114) Burdyga G, Varro A, Dimaline R, Thompson DG, Dockray GJ. Ghrelin receptors in rat and human nodose ganglia: putative role in regulating $\mathrm{CB}-1$ and $\mathrm{MCH}$ receptor abundance. American journal of physiology. Gastrointestinal and liver physiology 2006; 290: G1289-97.

115) Rocca AS, Brubaker PL. Role of the vagus nerve in mediating proximal nutrient-induced glucagon-like peptide-1 secretion. Endocrinology 1999; 140: $1687-94$.

116) Anini Y, Brubaker PL. Muscarinic receptors control glucagon-like peptide 1 secretion by human endocrine L cells. Endocrinology 2003; 144: 3244-50. 
117) Ruttimann EB, Arnold M, Hillebrand JJ, Geary N, Langhans W. Intrameal hepatic portal and intraperitoneal infusions of glucagon-like peptide-1 reduce spontaneous meal size in the rat via different mechanisms. Endocrinology 2009; 150: 1174-81.

118) Ruttimann EB, Arnold M, Geary N, Langhans W. GLP-1 antagonism with exendin (9-39) fails to increase spontaneous meal size in rats. Physiology \& behavior 2010; 100: 291-6.

119) Chelikani PK, Haver AC, Reidelberger RD. Intravenous infusion of glucagonlike peptide-1 potently inhibits food intake, sham feeding, and gastric emptying in rats. American journal of physiology. Regulatory, integrative and comparative physiology 2005; 288: R1695-706.

120) Batterham RL, Cowley MA, Small CJ, Herzog H, Cohen MA, Dakin CL, Wren AM, Brynes AE, Low M), Ghatei MA, Cone RD, Bloom SR. Gut hormone PYY(336) physiologically inhibits food intake. Nature 2002; 418: 650-4.

121) Beglinger C, Degen L. Gastrointestinal satiety signals in humans--physiologic roles for GLP-1 and PYY? Physiology \& behavior 2006; 89: 460-4.

122) Degen L, Oesch S, Casanova M, Graf S, Ketterer S, Drewe J, Beglinger C. Effect of peptide YY3-36 on food intake in humans. Gastroenterology 2005; 129: $1430-6$.

123) Stadlbauer U, Arnold M, Weber E, Langhans W. Possible mechanisms of circulating PYY-induced satiation in male rats. Endocrinology 2013; 154: 193-204.

124) Abbott CR, Small CJ, Kennedy AR, Neary NM, Sajedi A, Ghatei MA, Bloom SR. Blockade of the neuropeptide Y Y2 receptor with the specific antagonist BIIE0246 attenuates the effect of endogenous and exogenous peptide YY(336 ) on food intake. Brain research 2005; 1043: 139-44.

125) Koda S, Date $Y$, Murakami N, Shimbara T, Hanada T, Toshinai K, Niijima A, Furuya M, Inomata N, Osuye K, Nakazato $M$. The role of the vagal nerve in peripheral PYY3-36-induced feeding reduction in rats. Endocrinology 2005; 146: 2369-75.

126) Blouet C, Schwartz GJ. Brainstem nutrient sensing in the nucleus of the solitary tract inhibits feeding. Cell metabolism 2012; 16: 579-87.

127) Mayer J. Glucostatic mechanism of regulation of food intake. The New England journal of medicine 1953; 249: 13-6. 
128) Anand BK, Chhina GS, Sharma KN, Dua S, Singh B. Activity of Single Neurons in the Hypothalamic Feeding Centers: Effect of Glucose. The American journal of physiology 1964; 207: 1146-54.

129) Oomura Y, Kimura K, Ooyama H, Maeno T, Iki M, Kuniyoshi M. Reciprocal Activities of the Ventromedial and Lateral Hypothalamic Areas of Cats. Science 1964; 143: 484-5.

130) Oomura Y, Ooyama H, Sugimori M, Nakamura T, Yamada Y. Glucose inhibition of the glucose-sensitive neurone in the rat lateral hypothalamus. Nature 1974; 247: 284-6.

131) Rowe IC, Boden PR, Ashford ML. Potassium channel dysfunction in hypothalamic glucose-receptive neurones of obese Zucker rats. The Journal of physiology 1996; 497 ( Pt 2): 365-77.

132) Song Z, Levin BE, McArdle JJ, Bakhos N, Routh VH. Convergence of pre- and postsynaptic influences on glucosensing neurons in the ventromedial hypothalamic nucleus. Diabetes 2001; 50: 2673-81.

133) Ashford ML, Boden PR, Treherne JM. Glucose-induced excitation of hypothalamic neurones is mediated by ATP-sensitive $\mathrm{K}+$ channels. Pflugers Archiv : European journal of physiology 1990; 415: 479-83.

134) Dunn-Meynell AA, Sanders NM, Compton D, Becker TC, Eiki J, Zhang BB, Levin BE. Relationship among brain and blood glucose levels and spontaneous and glucoprivic feeding. The Journal of neuroscience : the official journal of the Society for Neuroscience 2009; 29: 7015-22.

135) Kang L, Dunn-Meynell AA, Routh VH, Gaspers LD, Nagata Y, Nishimura T, Eiki J, Zhang BB, Levin BE. Glucokinase is a critical regulator of ventromedial hypothalamic neuronal glucosensing. Diabetes 2006; 55: 412-20.

136) Kang L, Routh VH, Kuzhikandathil EV, Gaspers LD, Levin BE. Physiological and molecular characteristics of rat hypothalamic ventromedial nucleus glucosensing neurons. Diabetes 2004; 53: 549-59.

137) Gonzalez JA, Jensen LT, Fugger L, Burdakov D. Metabolism-independent sugar sensing in central orexin neurons. Diabetes 2008; 57: 2569-76.

138) MacDonald PE, Eliasson L, Rorsman P. Calcium increases endocytotic vesicle size and accelerates membrane fission in insulin-secreting INS-1 cells. Journal of cell science 2005; 118: 5911-20.

139) Wang R, Liu X, Hentges ST, Dunn-Meynell AA, Levin BE, Wang W, Routh VH. The regulation of glucose-excited neurons in the hypothalamic arcuate 
nucleus by glucose and feeding-relevant peptides. Diabetes 2004; 53: 195965.

140) Claret M, Smith MA, Batterham RL, Selman C, Choudhury AI, Fryer LG, Clements M, Al-Qassab H, Heffron H, Xu AW, Speakman JR, Barsh GS, Viollet $B$, Vaulont S, Ashford ML, Carling D, Withers DJ. AMPK is essential for energy homeostasis regulation and glucose sensing by POMC and AgRP neurons. The Journal of clinical investigation 2007; 117: 2325-36.

141) Cotero VE, Routh VH. Insulin blunts the response of glucose-excited neurons in the ventrolateral-ventromedial hypothalamic nucleus to decreased glucose. American journal of physiology. Endocrinology and metabolism 2009; 296: E1101-9.

142) Ibrahim N, Bosch MA, Smart JL, Qiu J, Rubinstein M, Ronnekleiv OK, Low MJ, Kelly MJ. Hypothalamic proopiomelanocortin neurons are glucose responsive and express K(ATP) channels. Endocrinology 2003; 144: 1331-40.

143) Plum L, Ma X, Hampel B, Balthasar N, Coppari R, Munzberg H, Shanabrough M, Burdakov D, Rother E, Janoschek R, Alber J, Belgardt BF, Koch L, Seibler J, Schwenk F, Fekete C, Suzuki A, Mak TW, Krone W, Horvath TL, Ashcroft FM, Bruning JC. Enhanced PIP3 signaling in POMC neurons causes KATP channel activation and leads to diet-sensitive obesity. The Journal of clinical investigation 2006; 116: 1886-901.

144) Fioramonti X, Contie S, Song Z, Routh VH, Lorsignol A, Penicaud L. Characterization of glucosensing neuron subpopulations in the arcuate nucleus: integration in neuropeptide $\mathrm{Y}$ and pro-opio melanocortin networks? Diabetes 2007; 56: 1219-27.

145) Dunn-Meynell AA, Routh VH, Kang L, Gaspers L, Levin BE. Glucokinase is the likely mediator of glucosensing in both glucose-excited and glucose-inhibited central neurons. Diabetes 2002; 51: 2056-65.

146) Murphy BA, Fakira KA, Song Z, Beuve A, Routh VH. AMP-activated protein kinase and nitric oxide regulate the glucose sensitivity of ventromedial hypothalamic glucose-inhibited neurons. American journal of physiology. Cell physiology 2009; 297: C750-8.

147) Canabal DD, Song Z, Potian JG, Beuve A, McArdle JJ, Routh VH. Glucose, insulin, and leptin signaling pathways modulate nitric oxide synthesis in glucose-inhibited neurons in the ventromedial hypothalamus. American journal of physiology. Regulatory, integrative and comparative physiology 2007; 292: R1418-28. 
148) Campfield LA, Smith FJ. Transient declines in blood glucose signal meal initiation. International journal of obesity 1990; 14 Suppl 3: 15-31; discussion 31-4.

149) Langhans W, Grossmann F, Geary N. Intrameal hepatic-portal infusion of glucose reduces spontaneous meal size in rats. Physiology \& behavior 2001; 73: 499-507.

150) Tordoff MG, Friedman MI. Hepatic portal glucose infusions decrease food intake and increase food preference. The American journal of physiology 1986; 251: R192-6.

151) Oomura $Y$, Nakamura $T$, Sugimori M, Yamada Y. Effect of free fatty acid on the rat lateral hypothalamic neurons. Physiology \& behavior 1975; 14: 483-6.

152) Wang R, Cruciani-Guglielmacci $C$, Migrenne S, Magnan C, Cotero VE, Routh VH. Effects of oleic acid on distinct populations of neurons in the hypothalamic arcuate nucleus are dependent on extracellular glucose levels. Journal of neurophysiology 2006; 95: 1491-8.

153) Le Foll C, Irani BG, Magnan C, Dunn-Meynell AA, Levin BE. Characteristics and mechanisms of hypothalamic neuronal fatty acid sensing. American journal of physiology. Regulatory, integrative and comparative physiology 2009; 297: R655-64.

154) Moulle VS, Le Foll C, Philippe E, Kassis N, Rouch C, Marsollier N, Bui LC, Guissard C, Dairou J, Lorsignol A, Penicaud L, Levin BE, Cruciani-Guglielmacci C, Magnan C. Fatty acid transporter CD36 mediates hypothalamic effect of fatty acids on food intake in rats. PloS one 2013; 8: e74021.

155) Loftus TM, Jaworsky DE, Frehywot GL, Townsend CA, Ronnett GV, Lane MD, Kuhajda FP. Reduced food intake and body weight in mice treated with fatty acid synthase inhibitors. Science 2000; 288: 2379-81.

156) Shu IW, Lindenberg DL, Mizuno TM, Roberts JL, Mobbs CV. The fatty acid synthase inhibitor cerulenin and feeding, like leptin, activate hypothalamic pro-opiomelanocortin (POMC) neurons. Brain research 2003; 985: 1-12.

157) Kim EK, Miller I, Aja S, Landree LE, Pinn M, McFadden J, Kuhajda FP, Moran $\mathrm{TH}$, Ronnett GV. C75, a fatty acid synthase inhibitor, reduces food intake via hypothalamic AMP-activated protein kinase. The Journal of biological chemistry 2004; 279: 19970-6.

158) Obici S, Feng Z, Morgan K, Stein D, Karkanias G, Rossetti L. Central administration of oleic acid inhibits glucose production and food intake. Diabetes 2002; 51: 271-5. 
159) Obici S, Rossetti L. Minireview: nutrient sensing and the regulation of insulin action and energy balance. Endocrinology 2003; 144: 5172-8.

160) Morgan BP, Griffiths M, Khanom H, Taylor SM, Neal JW. Blockade of the C5a receptor fails to protect against experimental autoimmune encephalomyelitis in rats. Clinical and experimental immunology 2004; 138: 430-8.

161) Boden G. Obesity, insulin resistance and free fatty acids. Current opinion in endocrinology, diabetes, and obesity 2011; 18: 139-43.

162) Auestad N, Korsak RA, Morrow JW, Edmond J. Fatty acid oxidation and ketogenesis by astrocytes in primary culture. Journal of neurochemistry 1991; 56: 1376-86.

163) Owen OE, Morgan AP, Kemp HG, Sullivan JM, Herrera MG, Cahill GF, Jr. Brain metabolism during fasting. The Journal of clinical investigation 1967; 46: 1589-95.

164) Guzman M, Blazquez C. Is there an astrocyte-neuron ketone body shuttle? Trends in endocrinology and metabolism: TEM 2001; 12: 169-73.

165) Cota D, Proulx K, Smith KA, Kozma SC, Thomas G, Woods SC, Seeley RJ. Hypothalamic mTOR signaling regulates food intake. Science 2006; 312: $927-$ 30.

166) Cota D, Matter EK, Woods SC, Seeley RJ. The role of hypothalamic mammalian target of rapamycin complex 1 signaling in diet-induced obesity. The Journal of neuroscience : the official journal of the Society for Neuroscience 2008; 28 : 7202-8.

167) Blouet C, Ono H, Schwartz GJ. Mediobasal hypothalamic p70 S6 kinase 1 modulates the control of energy homeostasis. Cell metabolism 2008; 8: 45967.

168) Blouet C, Jo YH, Li X, Schwartz GJ. Mediobasal hypothalamic leucine sensing regulates food intake through activation of a hypothalamus-brainstem circuit. The Journal of neuroscience : the official journal of the Society for Neuroscience 2009; 29: 8302-11.

169) Bagdade JD, Bierman EL, Porte D, Jr. The significance of basal insulin levels in the evaluation of the insulin response to glucose in diabetic and nondiabetic subjects. The Journal of clinical investigation 1967; 46: 1549-57.

170) Bernstein IL, Lotter EC, Kulkosky PJ, Porte D, Jr., Woods SC. Effect of forcefeeding upon basal insulin levels of rats. Proceedings of the Society for 
Experimental Biology and Medicine. Society for Experimental Biology and Medicine 1975; 150: 546-8.

171) Woods SC, Decke E, Vasselli JR. Metabolic hormones and regulation of body weight. Psychological review 1974; 81: 26-43.

172) Polonsky KS, Given BD, Van Cauter E. Twenty-four-hour profiles and pulsatile patterns of insulin secretion in normal and obese subjects. The Journal of clinical investigation 1988; 81: 442-8.

173) Woods SC, Lotter EC, McKay LD, Porte D, Jr. Chronic intracerebroventricular infusion of insulin reduces food intake and body weight of baboons. Nature 1979; 282: 503-5.

174) Riedy CA, Chavez M, Figlewicz DP, Woods SC. Central insulin enhances sensitivity to cholecystokinin. Physiology \& behavior 1995; 58: 755-60.

175) Lotter EC, Woods SC. Injections of insulin and changes of body weight. Physiology \& behavior 1977; 18: 293-7.

176) Chavez M, Seeley RJ, Woods SC. A comparison between effects of intraventricular insulin and intraperitoneal lithium chloride on three measures sensitive to emetic agents. Behavioral neuroscience 1995; 109: $547-50$.

177) Woods SC. From conditioned hypoglycemia to obesity: following the data. Physiology \& behavior 2013; 121: 19-24.

178) Geary N. Endocrine controls of eating: CCK, leptin, and ghrelin. Physiology \& behavior 2004; 81: 719-33.

179) Strubbe JH, Mein CG. Increased feeding in response to bilateral injection of insulin antibodies in the VMH. Physiology \& behavior 1977; 19: 309-13.

180) Bruning JC, Gautam D, Burks DJ, Gillette J, Schubert M, Orban PC, Klein R, Krone W, Muller-Wieland D, Kahn CR. Role of brain insulin receptor in control of body weight and reproduction. Science 2000; 289: 2122-5.

181) Gloy VL, Lutz TA, Langhans W, Geary N, Hillebrand JJ. Basal plasma levels of insulin, leptin, ghrelin, and amylin do not signal adiposity in rats recovering from forced overweight. Endocrinology 2010; 151: 4280-8.

182) Hillebrand JJ, Geary N. Do leptin and insulin signal adiposity? Forum of nutrition 2010; 63: 111-22. 
183) Zhang Y, Proenca R, Maffei M, Barone M, Leopold L, Friedman JM. Positional cloning of the mouse obese gene and its human homologue. Nature 1994; 372: 425-32.

184) Chua SC, Jr., Chung WK, Wu-Peng XS, Zhang Y, Liu SM, Tartaglia L, Leibel RL. Phenotypes of mouse diabetes and rat fatty due to mutations in the $\mathrm{OB}$ (leptin) receptor. Science 1996; 271: 994-6.

185) Banks WA, Kastin AJ, Huang W, Jaspan JB, Maness LM. Leptin enters the brain by a saturable system independent of insulin. Peptides 1996; 17: 305-11.

186) Cheung CC, Clifton DK, Steiner RA. Proopiomelanocortin neurons are direct targets for leptin in the hypothalamus. Endocrinology 1997; 138: 4489-92.

187) Cowley MA, Smart JL, Rubinstein M, Cerdan MG, Diano S, Horvath TL, Cone $\mathrm{RD}$, Low MJ. Leptin activates anorexigenic POMC neurons through a neural network in the arcuate nucleus. Nature 2001; 411: 480-4.

188) Konner AC, Janoschek R, Plum L, Jordan SD, Rother E, Ma X, Xu C, Enriori P, Hampel B, Barsh GS, Kahn CR, Cowley MA, Ashcroft FM, Bruning JC. Insulin action in AgRP-expressing neurons is required for suppression of hepatic glucose production. Cell metabolism 2007; 5: 438-49.

189) Grill HJ, Schwartz MW, Kaplan JM, Foxhall JS, Breininger J, Baskin DG. Evidence that the caudal brainstem is a target for the inhibitory effect of leptin on food intake. Endocrinology 2002; 143: 239-46.

190) Sinha MK, Ohannesian JP, Heiman ML, Kriauciunas A, Stephens TW, Magosin S, Marco C, Caro JF. Nocturnal rise of leptin in lean, obese, and non-insulindependent diabetes mellitus subjects. The Journal of clinical investigation 1996; 97: 1344-7.

191) Flynn MC, Scott TR, Pritchard TC, Plata-Salaman CR. Mode of action of OB protein (leptin) on feeding. The American journal of physiology 1998; 275: R174-9.

192) Ho A, Chin A. Circadian feeding and drinking patterns of genetically obese mice fed solid chow diet. Physiology \& behavior 1988; 43: 651-6.

193) Zhang Y, Guo K, LeBlanc RE, Loh D, Schwartz GJ, Yu YH. Increasing dietary leucine intake reduces diet-induced obesity and improves glucose and cholesterol metabolism in mice via multimechanisms. Diabetes 2007; 56: 1647-54. 
194) Vaisse C, Halaas JL, Horvath CM, Darnell JE, Jr., Stoffel M, Friedman JM. Leptin activation of Stat3 in the hypothalamus of wild-type and ob/ob mice but not $\mathrm{db} / \mathrm{db}$ mice. Nature genetics 1996; 14: 95-7.

195) Mesaros A, Koralov SB, Rother E, Wunderlich FT, Ernst MB, Barsh GS, Rajewsky K, Bruning JC. Activation of Stat3 signaling in AgRP neurons promotes locomotor activity. Cell metabolism 2008; 7: 236-48.

196) Ernst MB, Wunderlich CM, Hess S, Paehler M, Mesaros A, Koralov SB, Kleinridders A, Husch A, Munzberg H, Hampel B, Alber J, Kloppenburg P, Bruning JC, Wunderlich FT. Enhanced Stat3 activation in POMC neurons provokes negative feedback inhibition of leptin and insulin signaling in obesity. The Journal of neuroscience : the official journal of the Society for Neuroscience 2009; 29: 11582-93.

197) Belgardt BF, Husch A, Rother E, Ernst MB, Wunderlich FT, Hampel B, Klockener T, Alessi D, Kloppenburg P, Bruning JC. PDK1 deficiency in POMCexpressing cells reveals FOXO1-dependent and -independent pathways in control of energy homeostasis and stress response. Cell metabolism 2008; 7: 291-301.

198) Hill JW, Xu Y, Preitner F, Fukuda M, Cho YR, Luo J, Balthasar N, Coppari R, Cantley LC, Kahn BB, Zhao JJ, Elmquist JK. Phosphatidyl inositol 3-kinase signaling in hypothalamic proopiomelanocortin neurons contributes to the regulation of glucose homeostasis. Endocrinology 2009; 150: 4874-82.

199) Niswender KD, Morrison CD, Clegg DJ, Olson R, Baskin DG, Myers MG, Jr., Seeley RJ, Schwartz MW. Insulin activation of phosphatidylinositol 3-kinase in the hypothalamic arcuate nucleus: a key mediator of insulin-induced anorexia. Diabetes 2003; 52: 227-31.

200) Ren H, Orozco IJ, Su Y, Suyama S, Gutierrez-Juarez R, Horvath TL, Wardlaw SL, Plum L, Arancio O, Accili D. Fox01 target Gpr17 activates AgRP neurons to regulate food intake. Cell 2012; 149: 1314-26.

201) Kim MS, Pak YK, Jang PG, Namkoong C, Choi YS, Won JC, Kim KS, Kim SW, Kim HS, Park JY, Kim YB, Lee KU. Role of hypothalamic Foxo1 in the regulation of food intake and energy homeostasis. Nature neuroscience 2006; 9: 901-6.

202) Kitamura T, Feng Y, Kitamura YI, Chua SC, Jr., Xu AW, Barsh GS, Rossetti L, Accili D. Forkhead protein Fox01 mediates Agrp-dependent effects of leptin on food intake. Nature medicine 2006; 12: 534-40.

203) Andrews ZB, Liu ZW, Walllingford N, Erion DM, Borok E, Friedman JM, Tschop MH, Shanabrough M, Cline G, Shulman GI, Coppola A, Gao XB, Horvath 
TL, Diano S. UCP2 mediates ghrelin's action on NPY/AgRP neurons by lowering free radicals. Nature 2008; 454: 846-51.

204) Ono H, Pocai A, Wang Y, Sakoda H, Asano T, Backer JM, Schwartz GJ, Rossetti L. Activation of hypothalamic S6 kinase mediates diet-induced hepatic insulin resistance in rats. The Journal of clinical investigation 2008; 118: 2959-68.

205) Elmquist JK, Coppari R, Balthasar N, Ichinose M, Lowell BB. Identifying hypothalamic pathways controlling food intake, body weight, and glucose homeostasis. J Comp Neurol 2005; 493: 63-71.

206) Woods SC. The control of food intake: behavioral versus molecular perspectives. Cell metabolism 2009; 9: 489-98.

207) Huszar D, Lynch CA, Fairchild-Huntress V, Dunmore JH, Fang Q, Berkemeier LR, Gu W, Kesterson RA, Boston BA, Cone RD, Smith FJ, Campfield LA, Burn P, Lee F. Targeted disruption of the melanocortin-4 receptor results in obesity in mice. Cell 1997; 88: 131-41.

208) Butler AA, Kesterson RA, Khong K, Cullen MJ, Pelleymounter MA, Dekoning J, Baetscher M, Cone RD. A unique metabolic syndrome causes obesity in the melanocortin-3 receptor-deficient mouse. Endocrinology 2000; 141: 351821.

209) Chen AS, Metzger JM, Trumbauer ME, Guan XM, Yu H, Frazier EG, Marsh DJ, Forrest MJ, Gopal-Truter S, Fisher J, Camacho RE, Strack AM, Mellin TN, MacIntyre DE, Chen HY, Van der Ploeg LH. Role of the melanocortin-4 receptor in metabolic rate and food intake in mice. Transgenic research 2000; 9: 145-54.

210) Kask A, Rago L, Wikberg JE, Schioth HB. Differential effects of melanocortin peptides on ingestive behaviour in rats: evidence against the involvement of MC(3) receptor in the regulation of food intake. Neuroscience letters 2000; 283: $1-4$.

211) Savontaus E, Breen TL, Kim A, Yang LM, Chua SC, Jr., Wardlaw SL. Metabolic effects of transgenic melanocyte-stimulating hormone overexpression in lean and obese mice. Endocrinology 2004; 145: 3881-91.

212) Lee M, Kim A, Chua SC, Jr., Obici S, Wardlaw SL. Transgenic MSH overexpression attenuates the metabolic effects of a high-fat diet. American journal of physiology. Endocrinology and metabolism 2007; 293: E121-31.

213) Li G, Mobbs CV, Scarpace PJ. Central pro-opiomelanocortin gene delivery results in hypophagia, reduced visceral adiposity, and improved insulin sensitivity in genetically obese Zucker rats. Diabetes 2003; 52: 1951-7. 
214) Zhang Y, Rodrigues E, Gao YX, King M, Cheng KY, Erdos B, Tumer N, Carter C, Scarpace PJ. Pro-opiomelanocortin gene transfer to the nucleus of the solitary track but not arcuate nucleus ameliorates chronic diet-induced obesity. Neuroscience 2010; 169: 1662-71.

215) Andino LM, Ryder DJ, Shapiro A, Matheny MK, Zhang Y, Judge MK, Cheng KY, Tumer N, Scarpace PJ. POMC overexpression in the ventral tegmental area ameliorates dietary obesity. The Journal of endocrinology 2011; 210: 199207.

216) Aponte Y, Atasoy D, Sternson SM. AGRP neurons are sufficient to orchestrate feeding behavior rapidly and without training. Nature neuroscience 2011; 14: 351-5.

217) Eerola K, Nordlund W, Virtanen S, Dickens AM, Mattila M, Ruohonen ST, Chua SC, Jr., Wardlaw SL, Savontaus M, Savontaus E. Lentivirus mediated alphamelanocyte stimulating hormone overexpression in the hypothalamus decreases diet induced obesity in mice. Journal of neuroendocrinology 2013;

218) Bronstein DM, Schafer MK, Watson SJ, Akil H. Evidence that beta-endorphin is synthesized in cells in the nucleus tractus solitarius: detection of POMC mRNA. Brain research 1992; 587: 269-75.

219) Padilla SL, Reef D, Zeltser LM. Defining POMC neurons using transgenic reagents: impact of transient Pomc expression in diverse immature neuronal populations. Endocrinology 2012; 153: 1219-31.

220) Seeley RJ, Yagaloff KA, Fisher SL, Burn P, Thiele TE, van Dijk G, Baskin DG, Schwartz MW. Melanocortin receptors in leptin effects. Nature 1997; 390: 349.

221) Grill HJ, Ginsberg AB, Seeley RJ, Kaplan JM. Brainstem application of melanocortin receptor ligands produces long-lasting effects on feeding and body weight. The Journal of neuroscience : the official journal of the Society for Neuroscience 1998; 18: 10128-35.

222) Williams DL, Kaplan JM, Grill HJ. The role of the dorsal vagal complex and the vagus nerve in feeding effects of melanocortin-3/4 receptor stimulation. Endocrinology 2000; 141: 1332-7.

223) Williams DL, Grill HJ, Weiss SM, Baird JP, Kaplan JM. Behavioral processes underlying the intake suppressive effects of melanocortin 3/4 receptor activation in the rat. Psychopharmacology 2002; 161: 47-53. 
224) Zheng $H$, Patterson LM, Phifer CB, Berthoud HR. Brain stem melanocortinergic modulation of meal size and identification of hypothalamic POMC projections. American journal of physiology. Regulatory, integrative and comparative physiology 2005; 289: R247-58.

225) Zhan C, Zhou J, Feng Q, Zhang JE, Lin S, Bao J, Wu P, Luo M. Acute and longterm suppression of feeding behavior by POMC neurons in the brainstem and hypothalamus, respectively. The Journal of neuroscience : the official journal of the Society for Neuroscience 2013; 33: 3624-32.

226) Zheng H, Patterson LM, Rhodes CJ, Louis GW, Skibicka KP, Grill HJ, Myers MG, Jr., Berthoud HR. A potential role for hypothalamomedullary POMC projections in leptin-induced suppression of food intake. American journal of physiology. Regulatory, integrative and comparative physiology 2010; 298: R720-8.

227) Williams KW, Margatho LO, Lee CE, Choi M, Lee S, Scott MM, Elias CF, Elmquist JK. Segregation of acute leptin and insulin effects in distinct populations of arcuate proopiomelanocortin neurons. The Journal of neuroscience : the official journal of the Society for Neuroscience 2010; 30: 2472-9.

228) Sohn JW, Xu Y, Jones JE, Wickman K, Williams KW, Elmquist JK. Serotonin 2C receptor activates a distinct population of arcuate pro-opiomelanocortin neurons via TRPC channels. Neuron 2011; 71: 488-97.

229) Al-Qassab H, Smith MA, Irvine EE, Guillermet-Guibert J, Claret M, Choudhury AI, Selman C, Piipari K, Clements M, Lingard S, Chandarana K, Bell JD, Barsh GS, Smith AJ, Batterham RL, Ashford ML, Vanhaesebroeck B, Withers DJ. Dominant role of the p110beta isoform of PI3K over p110alpha in energy homeostasis regulation by POMC and AgRP neurons. Cell metabolism 2009; 10: 343-54.

230) O'Donohue TL, Dorsa DM. The opiomelanotropinergic neuronal and endocrine systems. Peptides 1982; 3: 353-95.

231) Bunel DT, Delbende C, Blasquez C, Jegou S, Vaudry H. Effects of ions and ionic channel activators or blockers on release of alpha-MSH from perifused rat hypothalamic slices. Brain research. Molecular brain research 1990; 8: 16775 .

232) MacMillan SJ, Mark MA, Duggan AW. The release of beta-endorphin and the neuropeptide-receptor mismatch in the brain. Brain research 1998; 794: 127-36. 
233) Leranth C, Williams TH, Chretien M, Palkovits M. Ultrastructural investigation of ACTH immunoreactivity in arcuate and supraoptic nuclei of the rat. Cell and tissue research 1980; 210: 11-9.

234) Buma P, Nieuwenhuys R. Ultrastructural characterization of exocytotic release sites in different layers of the median eminence of the rat. Cell and tissue research 1988; 252: 107-14.

235) Buma P, Veening J, Nieuwenhuys R. Ultrastructural Characterization of Adrenocorticotrope Hormone (ACTH) Immunoreactive Fibres in the Mesencephalic Central Grey Substance of the Rat. The European journal of neuroscience 1989; 1: 659-72.

236) Golding DW. A pattern confirmed and refined--synaptic, nonsynaptic and parasynaptic exocytosis. BioEssays : news and reviews in molecular, cellular and developmental biology 1994; 16: 503-8.

237) Agnati LF, Zoli M, Stromberg I, Fuxe K. Intercellular communication in the brain: wiring versus volume transmission. Neuroscience 1995; 69: 711-26.

238) Kaye WH, Berrettini WH, Gwirtsman HE, Chretien M, Gold PW, George DT, Jimerson DC, Ebert MH. Reduced cerebrospinal fluid levels of immunoreactive pro-opiomelanocortin related peptides (including betaendorphin) in anorexia nervosa. Life sciences 1987; 41: 2147-55.

239) Tsigos C, Crosby SR, Gibson S, Young RJ, White A. Proopiomelanocortin is the predominant adrenocorticotropin-related peptide in human cerebrospinal fluid. The Journal of clinical endocrinology and metabolism 1993; 76: 620-4.

240) Veening JG, Gerrits PO, Barendregt HP. Volume transmission of betaendorphin via the cerebrospinal fluid; a review. Fluids and barriers of the CNS 2012; 9: 16.

241) Murphy B, Nunes CN, Ronan JJ, Harper CM, Beall MJ, Hanaway M, Fairhurst AM, Van der Ploeg LH, MacIntyre DE, Mellin TN. Melanocortin mediated inhibition of feeding behavior in rats. Neuropeptides 1998; 32: 491-7.

242) Murphy B, Nunes CN, Ronan JJ, Hanaway M, Fairhurst AM, Mellin TN. Centrally administered MTII affects feeding, drinking, temperature, and activity in the Sprague-Dawley rat. Journal of applied physiology 2000; 89: 273-82.

243) Irani BG, Xiang Z, Yarandi HN, Holder JR, Moore MC, Bauzo RM, Proneth B, Shaw AM, Millard WJ, Chambers JB, Benoit SC, Clegg DJ, Haskell-Luevano C. Implication of the melanocortin-3 receptor in the regulation of food intake. European journal of pharmacology 2011; 660: 80-7. 
244) Azzara AV, Sokolnicki JP, Schwartz GJ. Central melanocortin receptor agonist reduces spontaneous and scheduled meal size but does not augment duodenal preload-induced feeding inhibition. Physiology \& behavior 2002; 77: 411-6.

245) Kim MS, Small CJ, Stanley SA, Morgan DG, Seal LJ, Kong WM, Edwards CM, Abusnana S, Sunter D, Ghatei MA, Bloom SR. The central melanocortin system affects the hypothalamo-pituitary thyroid axis and may mediate the effect of leptin. The Journal of clinical investigation 2000; 105: 1005-11.

246) Elias CF, Aschkenasi C, Lee C, Kelly J, Ahima RS, Bjorbaek C, Flier JS, Saper CB, Elmquist JK. Leptin differentially regulates NPY and POMC neurons projecting to the lateral hypothalamic area. Neuron 1999; 23: 775-86.

247) Korner J, Savontaus E, Chua SC, Jr., Leibel RL, Wardlaw SL. Leptin regulation of Agrp and Npy mRNA in the rat hypothalamus. Journal of neuroendocrinology 2001; 13: 959-66.

248) Balthasar N, Coppari R, McMinn J, Liu SM, Lee CE, Tang V, Kenny CD, McGovern RA, Chua SC, Jr., Elmquist JK, Lowell BB. Leptin receptor signaling in POMC neurons is required for normal body weight homeostasis. Neuron 2004; 42: 983-91.

249) Skibicka KP, Grill HJ. Hindbrain leptin stimulation induces anorexia and hyperthermia mediated by hindbrain melanocortin receptors. Endocrinology 2009; 150: 1705-11.

250) Williams DL, Bowers RR, Bartness TJ, Kaplan JM, Grill HJ. Brainstem melanocortin 3/4 receptor stimulation increases uncoupling protein gene expression in brown fat. Endocrinology 2003; 144: 4692-7.

251) Ellacott KL, Halatchev IG, Cone RD. Characterization of leptin-responsive neurons in the caudal brainstem. Endocrinology 2006; 147: 3190-5.

252) Benoit SC, Air EL, Coolen LM, Strauss R, Jackman A, Clegg DJ, Seeley RJ, Woods SC. The catabolic action of insulin in the brain is mediated by melanocortins. The Journal of neuroscience : the official journal of the Society for Neuroscience 2002; 22: 9048-52.

253) Kim EM, Grace MK, Welch CC, Billington CJ, Levine AS. STZ-induced diabetes decreases and insulin normalizes POMC mRNA in arcuate nucleus and pituitary in rats. The American journal of physiology 1999; 276: R1320-6.

254) Hill JW, Elias CF, Fukuda M, Williams KW, Berglund ED, Holland WL, Cho YR, Chuang JC, Xu Y, Choi M, Lauzon D, Lee CE, Coppari R, Richardson JA, Zigman 
JM, Chua S, Scherer PE, Lowell BB, Bruning JC, Elmquist JK. Direct insulin and leptin action on pro-opiomelanocortin neurons is required for normal glucose homeostasis and fertility. Cell metabolism 2010; 11: 286-97.

255) Lin HV, Plum L, Ono H, Gutierrez-Juarez R, Shanabrough M, Borok E, Horvath TL, Rossetti L, Accili D. Divergent regulation of energy expenditure and hepatic glucose production by insulin receptor in agouti-related protein and POMC neurons. Diabetes 2010; 59: 337-46.

256) Heisler LK, Cowley MA, Tecott LH, Fan W, Low MJ, Smart JL, Rubinstein M, Tatro JB, Marcus JN, Holstege H, Lee CE, Cone RD, Elmquist JK. Activation of central melanocortin pathways by fenfluramine. Science 2002; 297: 609-11.

257) Kiss J, Leranth C, Halasz B. Serotoninergic endings on VIP-neurons in the suprachiasmatic nucleus and on ACTH-neurons in the arcuate nucleus of the rat hypothalamus. A combination of high resolution autoradiography and electron microscopic immunocytochemistry. Neuroscience letters 1984; 44: $119-24$.

258) Zhou L, Sutton GM, Rochford JJ, Semple RK, Lam DD, Oksanen LJ, ThorntonJones ZD, Clifton PG, Yueh CY, Evans ML, McCrimmon RJ, Elmquist JK, Butler AA, Heisler LK. Serotonin 2C receptor agonists improve type 2 diabetes via melanocortin-4 receptor signaling pathways. Cell metabolism 2007; 6: 398405.

259) Lam DD, Przydzial MJ, Ridley SH, Yeo GS, Rochford JJ, O'Rahilly S, Heisler LK. Serotonin 5-HT2C receptor agonist promotes hypophagia via downstream activation of melanocortin 4 receptors. Endocrinology 2008; 149: 1323-8.

260) Xu Y, Jones JE, Kohno D, Williams KW, Lee CE, Choi MJ, Anderson JG, Heisler LK, Zigman JM, Lowell BB, Elmquist JK. 5-HT2CRs expressed by proopiomelanocortin neurons regulate energy homeostasis. Neuron 2008; 60: 582-9.

261) Xu Y, Jones JE, Lauzon DA, Anderson JG, Balthasar N, Heisler LK, Zinn AR, Lowell BB, Elmquist JK. A serotonin and melanocortin circuit mediates Dfenfluramine anorexia. The Journal of neuroscience : the official journal of the Society for Neuroscience 2010; 30: 14630-4.

262) Heisler LK, Jobst EE, Sutton GM, Zhou L, Borok E, Thornton-Jones Z, Liu HY, Zigman JM, Balthasar N, Kishi T, Lee CE, Aschkenasi CJ, Zhang CY, Yu J, Boss O, Mountjoy KG, Clifton PG, Lowell BB, Friedman JM, Horvath T, Butler AA, Elmquist JK, Cowley MA. Serotonin reciprocally regulates melanocortin neurons to modulate food intake. Neuron 2006; 51: 239-49. 
263) Berglund ED, Liu C, Sohn JW, Liu T, Kim MH, Lee CE, Vianna CR, Williams KW, $\mathrm{Xu}$ Y, Elmquist JK. Serotonin 2C receptors in pro-opiomelanocortin neurons regulate energy and glucose homeostasis. The Journal of clinical investigation 2013; 123: 5061-70.

264) Berglund ED, Vianna CR, Donato J, Jr., Kim MH, Chuang JC, Lee CE, Lauzon DA, Lin P, Brule LJ, Scott MM, Coppari R, Elmquist JK. Direct leptin action on POMC neurons regulates glucose homeostasis and hepatic insulin sensitivity in mice. The Journal of clinical investigation 2012; 122: 1000-9.

265) Hentges ST, Nishiyama M, Overstreet LS, Stenzel-Poore M, Williams JT, Low MJ. GABA release from proopiomelanocortin neurons. The Journal of neuroscience : the official journal of the Society for Neuroscience 2004; 24: 1578-83.

266) Hentges ST, Otero-Corchon V, Pennock RL, King CM, Low MJ. Proopiomelanocortin expression in both GABA and glutamate neurons. The Journal of neuroscience : the official journal of the Society for Neuroscience 2009; 29: 13684-90.

267) Jarvie BC, Hentges ST. Expression of GABAergic and glutamatergic phenotypic markers in hypothalamic proopiomelanocortin neurons. J Comp Neurol 2012; 520: 3863-76.

268) Ito $Y$, Banno R, Shibata $M$, Adachi K, Hagimoto $S$, Hagiwara D, Ozawa $Y$, Goto M, Suga H, Sugimura Y, Bettler B, Oiso Y, Arima H. GABA type B receptor signaling in proopiomelanocortin neurons protects against obesity, insulin resistance, and hypothalamic inflammation in male mice on a high-fat diet. The Journal of neuroscience : the official journal of the Society for Neuroscience 2013; 33: 17166-73.

269) Palou M, Sanchez J, Rodriguez AM, Priego T, Pico C, Palou A. Induction of NPY/AgRP orexigenic peptide expression in rat hypothalamus is an early event in fasting: relationship with circulating leptin, insulin and glucose. Cellular physiology and biochemistry : international journal of experimental cellular physiology, biochemistry, and pharmacology 2009; 23: 115-24.

270) Shutter JR, Graham M, Kinsey AC, Scully S, Luthy R, Stark KL. Hypothalamic expression of ART, a novel gene related to agouti, is up-regulated in obese and diabetic mutant mice. Genes \& development 1997; 11: 593-602.

271) Korner J, Wissig S, Kim A, Conwell IM, Wardlaw SL. Effects of agouti-related protein on metabolism and hypothalamic neuropeptide gene expression. Journal of neuroendocrinology 2003; 15: 1116-21. 
272) Graham M, Shutter JR, Sarmiento U, Sarosi I, Stark KL. Overexpression of Agrt leads to obesity in transgenic mice. Nature genetics 1997; 17: 273-4.

273) Krashes MJ, Koda S, Ye C, Rogan SC, Adams AC, Cusher DS, Maratos-Flier E, Roth BL, Lowell BB. Rapid, reversible activation of AgRP neurons drives feeding behavior in mice. The Journal of clinical investigation 2011; 121 : 1424-8.

274) Makimura H, Mizuno TM, Mastaitis JW, Agami R, Mobbs CV. Reducing hypothalamic AGRP by RNA interference increases metabolic rate and decreases body weight without influencing food intake. BMC neuroscience 2002; 3: 18.

275) van de Wall E, Leshan R, Xu AW, Balthasar N, Coppari R, Liu SM, Jo YH, MacKenzie RG, Allison DB, Dun NJ, Elmquist J, Lowell BB, Barsh GS, de Luca C, Myers MG, Jr., Schwartz GJ, Chua SC, Jr. Collective and individual functions of leptin receptor modulated neurons controlling metabolism and ingestion. Endocrinology 2008; 149: 1773-85.

276) Bewick GA, Gardiner JV, Dhillo WS, Kent AS, White NE, Webster Z, Ghatei MA, Bloom SR. Post-embryonic ablation of AgRP neurons in mice leads to a lean, hypophagic phenotype. FASEB journal : official publication of the Federation of American Societies for Experimental Biology 2005; 19: 1680-2.

277) Gropp E, Shanabrough M, Borok E, Xu AW, Janoschek R, Buch T, Plum L, Balthasar N, Hampel B, Waisman A, Barsh GS, Horvath TL, Bruning JC. Agoutirelated peptide-expressing neurons are mandatory for feeding. Nature neuroscience 2005; 8: 1289-91.

278) Luquet S, Perez FA, Hnasko TS, Palmiter RD. NPY/AgRP neurons are essential for feeding in adult mice but can be ablated in neonates. Science 2005; 310 : 683-5.

279) Xu AW, Kaelin CB, Morton GJ, Ogimoto K, Stanhope K, Graham J, Baskin DG, Havel P, Schwartz MW, Barsh GS. Effects of hypothalamic neurodegeneration on energy balance. PLoS biology 2005; 3: e415.

280) Michaud EJ, Bultman SJ, Klebig ML, van Vugt MJ, Stubbs LJ, Russell LB, Woychik RP. A molecular model for the genetic and phenotypic characteristics of the mouse lethal yellow (Ay) mutation. Proceedings of the National Academy of Sciences of the United States of America 1994; 91: 2562-6.

281) Ollmann MM, Wilson BD, Yang YK, Kerns JA, Chen Y, Gantz I, Barsh GS. Antagonism of central melanocortin receptors in vitro and in vivo by agoutirelated protein. Science 1997; 278: 135-8. 
282) Tolle V, Low MJ. In vivo evidence for inverse agonism of Agouti-related peptide in the central nervous system of proopiomelanocortin-deficient mice. Diabetes 2008; 57: 86-94.

283) Horvath TL, Bechmann I, Naftolin F, Kalra SP, Leranth C. Heterogeneity in the neuropeptide Y-containing neurons of the rat arcuate nucleus: GABAergic and non-GABAergic subpopulations. Brain research 1997; 756: 283-6.

284) Wu Q, Howell MP, Cowley MA, Palmiter RD. Starvation after AgRP neuron ablation is independent of melanocortin signaling. Proceedings of the National Academy of Sciences of the United States of America 2008; 105: 2687-92.

285) Kaelin CB, Gong L, Xu AW, Yao F, Hockman K, Morton GJ, Schwartz MW, Barsh GS, MacKenzie RG. Signal transducer and activator of transcription (stat) binding sites but not stat3 are required for fasting-induced transcription of agouti-related protein messenger ribonucleic acid. Molecular endocrinology 2006; 20: 2591-602.

286) Iskandar K, Cao $Y$, Hayashi $Y$, Nakata M, Takano E, Yada T, Zhang C, Ogawa W, Oki M, Chua S, Jr., Itoh H, Noda T, Kasuga M, Nakae J. PDK-1/FoxO1 pathway in POMC neurons regulates Pomc expression and food intake. American journal of physiology. Endocrinology and metabolism 2010; 298: E787-98.

287) Cao $Y$, Nakata M, Okamoto S, Takano E, Yada T, Minokoshi $Y$, Hirata $Y$, Nakajima K, Iskandar K, Hayashi Y, Ogawa W, Barsh GS, Hosoda H, Kangawa K, Itoh H, Noda T, Kasuga M, Nakae J. PDK1-Foxo1 in agouti-related peptide neurons regulates energy homeostasis by modulating food intake and energy expenditure. PloS one 2011; 6: e18324.

288) Gray TS, Morley JE. Neuropeptide Y: anatomical distribution and possible function in mammalian nervous system. Life sciences 1986; 38: 389-401.

289) Stanley BG, Kyrkouli SE, Lampert S, Leibowitz SF. Neuropeptide Y chronically injected into the hypothalamus: a powerful neurochemical inducer of hyperphagia and obesity. Peptides 1986; 7: 1189-92.

290) Leibowitz SF, Alexander JT. Analysis of neuropeptide Y-induced feeding: dissociation of Y1 and Y2 receptor effects on natural meal patterns. Peptides 1991; 12: 1251-60.

291) Lynch WC, Hart P, Babcock AM. Neuropeptide $Y$ attenuates satiety: evidence from a detailed analysis of patterns ingestion. Brain research 1994; 636: 2834. 
292) Stricker-Krongrad A, Barbanel G, Beck B, Burlet A, Nicolas JP, Burlet C. K(+)stimulated neuropeptide $\mathrm{Y}$ release into the paraventricular nucleus and relation to feeding behavior in free-moving rats. Neuropeptides 1993; 24 : $307-12$.

293) Corp ES, Melville LD, Greenberg D, Gibbs J, Smith GP. Effect of fourth ventricular neuropeptide $Y$ and peptide $Y Y$ on ingestive and other behaviors. The American journal of physiology 1990; 259: R317-23.

294) Taylor A, Redworth EW, Morgan JB. Influence of diet on iron, copper, and zinc status in children under 24 months of age. Biological trace element research 2004; 97: 197-214.

295) Yang L, Scott KA, Hyun J, Tamashiro KL, Tray N, Moran TH, Bi S. Role of dorsomedial hypothalamic neuropeptide $\mathrm{Y}$ in modulating food intake and energy balance. The Journal of neuroscience : the official journal of the Society for Neuroscience 2009; 29: 179-90.

296) Clark JT, Kalra PS, Crowley WR, Kalra SP. Neuropeptide Y and human pancreatic polypeptide stimulate feeding behavior in rats. Endocrinology 1984; 115: 427-9.

297) Levine AS, Morley JE. Neuropeptide Y: a potent inducer of consummatory behavior in rats. Peptides 1984; 5: 1025-9.

298) Stanley BG, Leibowitz SF. Neuropeptide Y: stimulation of feeding and drinking by injection into the paraventricular nucleus. Life sciences 1984; 35: 2635-42.

299) Dube MG, Xu B, Crowley WR, Kalra PS, Kalra SP. Evidence that neuropeptide $\mathrm{Y}$ is a physiological signal for normal food intake. Brain research 1994; 646: 341-4.

300) Shibasaki T, Oda T, Imaki T, Ling N, Demura H. Injection of anti-neuropeptide Y gamma-globulin into the hypothalamic paraventricular nucleus decreases food intake in rats. Brain research 1993; 601: 313-6.

301) Walter MJ, Scherrer JF, Flood JF, Morley JE. Effects of localized injections of neuropeptide $\mathrm{Y}$ antibody on motor activity and other behaviors. Peptides 1994; 15: 607-13.

302) Gardiner JV, Kong WM, Ward H, Murphy KG, Dhillo WS, Bloom SR. AAV mediated expression of anti-sense neuropeptide $\mathrm{Y}$ cRNA in the arcuate nucleus of rats results in decreased weight gain and food intake. Biochemical and biophysical research communications 2005; 327: 1088-93. 
303) Hulsey MG, Pless CM, White BD, Martin RJ. ICV administration of anti-NPY antisense oligonucleotide: effects on feeding behavior, body weight, peptide content and peptide release. Regulatory peptides 1995; 59: 207-14.

304) Chua SC, Jr., Brown AW, Kim J, Hennessey KL, Leibel RL, Hirsch J. Food deprivation and hypothalamic neuropeptide gene expression: effects of strain background and the diabetes mutation. Brain research. Molecular brain research 1991; 11: 291-9.

305) Sahu A, Kalra PS, Kalra SP. Food deprivation and ingestion induce reciprocal changes in neuropeptide $\mathrm{Y}$ concentrations in the paraventricular nucleus. Peptides 1988; 9: 83-6.

306) Sanacora G, Kershaw M, Finkelstein JA, White JD. Increased hypothalamic content of preproneuropeptide $\mathrm{Y}$ messenger ribonucleic acid in genetically obese Zucker rats and its regulation by food deprivation. Endocrinology 1990; 127: 730-7.

307) Schwartz GJ, Moran TH. Leptin and neuropeptide y have opposing modulatory effects on nucleus of the solitary tract neurophysiological responses to gastric loads: implications for the control of food intake. Endocrinology 2002; 143: 3779-84.

308) Beck B, Jhanwar-Uniyal M, Burlet A, Chapleur-Chateau M, Leibowitz SF, Burlet C. Rapid and localized alterations of neuropeptide $\mathrm{Y}$ in discrete hypothalamic nuclei with feeding status. Brain research 1990; 528: 245-9.

309) Bi S. Dorsomedial hypothalamic NPY modulation of adiposity and thermogenesis. Physiology \& behavior 2013; 121: 56-60.

310) Elmquist JK, Elias CF, Saper CB. From lesions to leptin: hypothalamic control of food intake and body weight. Neuron 1999; 22: 221-32.

311) Schwartz MW, Woods SC, Porte D, Jr., Seeley RJ, Baskin DG. Central nervous system control of food intake. Nature 2000; 404: 661-71.

312) Bi S, Robinson BM, Moran TH. Acute food deprivation and chronic food restriction differentially affect hypothalamic NPY mRNA expression. American journal of physiology. Regulatory, integrative and comparative physiology 2003; 285: R1030-6.

313) Chen J, Scott KA, Zhao Z, Moran TH, Bi S. Characterization of the feeding inhibition and neural activation produced by dorsomedial hypothalamic cholecystokinin administration. Neuroscience 2008; 152: 178-88. 
314) McMinn JE, Sindelar DK, Havel PJ, Schwartz MW. Leptin deficiency induced by fasting impairs the satiety response to cholecystokinin. Endocrinology 2000; 141: 4442-8.

315) Halford JC, Harrold JA, Boyland EJ, Lawton CL, Blundell JE. Serotonergic drugs : effects on appetite expression and use for the treatment of obesity. Drugs 2007; 67: 27-55.

316) Blundell JE. Is there a role for serotonin (5-hydroxytryptamine) in feeding? International journal of obesity 1977; 1: 15-42.

317) Halford JC, Blundell JE. Separate systems for serotonin and leptin in appetite control. Annals of medicine 2000; 32: 222-32.

318) Heisler LK, Cowley MA, Kishi T, Tecott LH, Fan W, Low MJ, Smart JL, Rubinstein M, Tatro J, Zigman JM, Cone RD, Elmquist JK. Central serotonin and melanocortin pathways regulating energy homeostasis. Annals of the New York Academy of Sciences 2003; 994: 169-74.

319) Bouwknecht JA, van der Gugten J, Hijzen TH, Maes RA, Hen R, Olivier B. Male and female 5-HT(1B) receptor knockout mice have higher body weights than wildtypes. Physiology \& behavior 2001; 74: 507-16.

320) Lee MD, Somerville EM, Kennett GA, Dourish CT, Clifton PG. Reduced hypophagic effects of d-fenfluramine and the 5 -HT2C receptor agonist mCPP in 5-HT1B receptor knockout mice. Psychopharmacology 2004; 176: 39-49.

321) Halford JC, Blundell JE. The 5-HT1B receptor agonist CP-94,253 reduces food intake and preserves the behavioural satiety sequence. Physiology \& behavior 1996; 60: 933-9.

322) Lee MD, Simansky KJ. CP-94, 253: a selective serotonin1B (5-HT1B) agonist that promotes satiety. Psychopharmacology 1997; 131: 264-70.

323) Lee MD, Aloyo VJ, Fluharty SJ, Simansky KJ. Infusion of the serotonin1B (5HT1B) agonist CP-93,129 into the parabrachial nucleus potently and selectively reduces food intake in rats. Psychopharmacology 1998; 136: 3047.

324) Blundell J, Latham C. Pharmacological manipulation of feeding behaviour: possible influences of serotonin and dopamine on food intake. In: Garattini S,Samanin R. Central mechanism of anorectic drugs. Raven, New York., 1978: 83-109. 
325) Blundell J, McArthur R. Behavioural flux and feeding: continuous monitoring of food intake and food selection, and the video-recording of appetitive and satiety sequences for the anlysis of drug action. In: Samanin R,Garattini S. Anorectic agents: mechanisms of action and tolerance. Raven, New York, 1981: 19-43.

326) Halford J, Blundell J. 5-Hydroxytrypaminergic drugs compared on the behavioural sequence associated with satiety. Br J Pharmacol 1993; 100: 95.

327) Clifton P. The neuropharmacology of meal patterning. In: Ethology and psychopharmacology. Wiley, Chichester., 1994: 313-28.

328) Vickers SP, Clifton PG, Dourish CT, Tecott LH. Reduced satiating effect of dfenfluramine in serotonin 5-HT(2C) receptor mutant mice. Psychopharmacology 1999; 143: 309-14.

329) Vickers SP, Dourish CT, Kennett GA. Evidence that hypophagia induced by dfenfluramine and d-norfenfluramine in the rat is mediated by 5-HT2C receptors. Neuropharmacology 2001; 41: 200-9.

330) Kennett GA, Curzon G. Evidence that hypophagia induced by mCPP and TFMPP requires 5-HT1C and 5-HT1B receptors; hypophagia induced by RU 24969 only requires 5-HT1B receptors. Psychopharmacology 1988; 96: 93100.

331) Halford JC, Wanninayake SC, Blundell JE. Behavioral satiety sequence (BSS) for the diagnosis of drug action on food intake. Pharmacol Biochem Behav 1998; 61: 159-68.

332) Tecott LH, Sun LM, Akana SF, Strack AM, Lowenstein DH, Dallman MF, Julius D. Eating disorder and epilepsy in mice lacking 5-HT2c serotonin receptors. Nature 1995; 374: 542-6.

333) Nonogaki K, Abdallah L, Goulding EH, Bonasera SJ, Tecott LH. Hyperactivity and reduced energy cost of physical activity in serotonin 5-HT(2C) receptor mutant mice. Diabetes 2003; 52: 315-20.

334) Grignaschi G, Mantelli B, Fracasso C, Anelli M, Caccia S, Samanin R. Reciprocal interaction of 5-hydroxytryptamine and cholecystokinin in the control of feeding patterns in rats. Br J Pharmacol 1993; 109: 491-4.

335) Poeschla B, Gibbs J, Simansky KJ, Greenberg D, Smith GP. Cholecystokinininduced satiety depends on activation of 5-HT1C receptors. The American journal of physiology 1993; 264: R62-4. 
336) Stallone D, Nicolaidis S, Gibbs J. Cholecystokinin-induced anorexia depends on serotoninergic function. The American journal of physiology 1989; 256: R1138-41.

337) Asarian L. Loss of cholecystokinin and glucagon-like peptide-1-induced satiation in mice lacking serotonin 2C receptors. American journal of physiology. Regulatory, integrative and comparative physiology 2009; 296: R51-6.

338) Guy J, Pelletier G, Bosler O. Serotonin innervation of neuropeptide Ycontaining neurons in the rat arcuate nucleus. Neuroscience letters 1988; 85: 9-13.

339) Choi S, Blake V, Cole S, Fernstrom JD. Effects of chronic fenfluramine administration on hypothalamic neuropeptide mRNA expression. Brain research 2006; 1087: 83-6.

340) Dryden S, Frankish HM, Wang Q, Pickavance L, Williams G. The serotonergic agent fluoxetine reduces neuropeptide $Y$ levels and neuropeptide $Y$ secretion in the hypothalamus of lean and obese rats. Neuroscience 1996; 72: 557-66.

341) Bendotti C, Garattini S, Samanin R. Eating caused by neuropeptide-Y injection in the paraventricular hypothalamus: response to (+)-fenfluramine and (+)amphetamine in rats. The Journal of pharmacy and pharmacology 1987; 39: 900-3.

342) Grignaschi G, Sironi F, Samanin R. The 5-HT1B receptor mediates the effect of d-fenfluramine on eating caused by intra-hypothalamic injection of neuropeptide Y. European journal of pharmacology 1995; 274: 221-4.

343) Arletti R, Benelli A, Bertolini A. Influence of oxytocin on feeding behavior in the rat. Peptides 1989; 10: 89-93.

344) Kublaoui BM, Gemelli T, Tolson KP, Wang Y, Zinn AR. Oxytocin deficiency mediates hyperphagic obesity of Sim1 haploinsufficient mice. Molecular endocrinology 2008; 22: 1723-34.

345) Tolson KP, Gemelli T, Gautron L, Elmquist JK, Zinn AR, Kublaoui BM. Postnatal Sim1 deficiency causes hyperphagic obesity and reduced Mc4r and oxytocin expression. The Journal of neuroscience : the official journal of the Society for Neuroscience 2010; 30: 3803-12.

346) Zhang G, Cai D. Circadian intervention of obesity development via restingstage feeding manipulation or oxytocin treatment. American journal of physiology. Endocrinology and metabolism 2011; 301: E1004-12. 
347) Lokrantz CM, Uvnas-Moberg K, Kaplan JM. Effects of central oxytocin administration on intraoral intake of glucose in deprived and nondeprived rats. Physiology \& behavior 1997; 62: 347-52.

348) Olszewski PK, Klockars A, Olszewska AM, Fredriksson R, Schioth HB, Levine AS. Molecular, immunohistochemical, and pharmacological evidence of oxytocin's role as inhibitor of carbohydrate but not fat intake. Endocrinology 2010; 151: 4736-44.

349) Blevins JE, Schwartz MW, Baskin DG. Evidence that paraventricular nucleus oxytocin neurons link hypothalamic leptin action to caudal brain stem nuclei controlling meal size. American journal of physiology. Regulatory, integrative and comparative physiology 2004; 287: R87-96.

350) Rinaman L, Vollmer RR, Karam J, Phillips D, Li X, Amico JA. Dehydration anorexia is attenuated in oxytocin-deficient mice. American journal of physiology. Regulatory, integrative and comparative physiology 2005; 288: R1791-9.

351) Camerino C. Low sympathetic tone and obese phenotype in oxytocindeficient mice. Obesity 2009; 17: 980-4.

352) Takayanagi $Y$, Kasahara $Y$, Onaka T, Takahashi N, Kawada T, Nishimori K. Oxytocin receptor-deficient mice developed late-onset obesity. Neuroreport 2008; 19: 951-5.

353) Deblon N, Veyrat-Durebex C, Bourgoin L, Caillon A, Bussier AL, Petrosino S, Piscitelli F, Legros JJ, Geenen V, Foti M, Wahli W, Di Marzo V, RohnerJeanrenaud F. Mechanisms of the anti-obesity effects of oxytocin in dietinduced obese rats. PloS one 2011; 6: e25565.

354) Morton GJ, Thatcher BS, Reidelberger RD, Ogimoto K, Wolden-Hanson T, Baskin DG, Schwartz MW, Blevins JE. Peripheral oxytocin suppresses food intake and causes weight loss in diet-induced obese rats. American journal of physiology. Endocrinology and metabolism 2012; 302: E134-44.

355) Sawchenko PE. Central connections of the sensory and motor nuclei of the vagus nerve. Journal of the autonomic nervous system 1983; 9: 13-26.

356) Rinaman L, Schwartz G. Anterograde transneuronal viral tracing of central viscerosensory pathways in rats. The Journal of neuroscience : the official journal of the Society for Neuroscience 2004; 24: 2782-6.

357) Wellman PJ. Norepinephrine and the control of food intake. Nutrition 2000; 16: 837-42. 
358) Callahan JB, Rinaman L. The postnatal emergence of dehydration anorexia in rats is temporally associated with the emergence of dehydration-induced inhibition of gastric emptying. Physiology \& behavior 1998; 64: 683-7.

359) Jelsing J, Galzin AM, Guillot E, Pruniaux MP, Larsen PJ, Vrang N. Localization and phenotypic characterization of brainstem neurons activated by rimonabant and WIN55,212-2. Brain research bulletin 2009; 78: 202-10.

360) Rinaman L. Oxytocinergic inputs to the nucleus of the solitary tract and dorsal motor nucleus of the vagus in neonatal rats. J Comp Neurol 1998; 399: 101-09.

361) Rinaman L. Hindbrain noradrenergic lesions attenuate anorexia and alter central cFos expression in rats after gastric viscerosensory stimulation. The Journal of neuroscience : the official journal of the Society for Neuroscience 2003; 23: 10084-92.

362) Rinaman L. Hindbrain noradrenergic A2 neurons: diverse roles in autonomic, endocrine, cognitive, and behavioral functions. American journal of physiology. Regulatory, integrative and comparative physiology 2011; 300: R222-35.

363) Uchoa ET, Sabino HA, Ruginsk SG, Antunes-Rodrigues J, Elias LL. Hypophagia induced by glucocorticoid deficiency is associated with an increased activation of satiety-related responses. Journal of applied physiology 2009; 106: 596-604.

364) Rinaman L, Baker EA, Hoffman GE, Stricker EM, Verbalis JG. Medullary c-Fos activation in rats after ingestion of a satiating meal. The American journal of physiology 1998; 275: R262-8.

365) Rinaman L, Verbalis JG, Stricker EM, Hoffman GE. Distribution and neurochemical phenotypes of caudal medullary neurons activated to express cFos following peripheral administration of cholecystokinin. J Comp Neurol 1993; 338: 475-90.

366) Rinaman L, Hoffman GE, Dohanics J, Le WW, Stricker EM, Verbalis JG. Cholecystokinin activates catecholaminergic neurons in the caudal medulla that innervate the paraventricular nucleus of the hypothalamus in rats. J Comp Neurol 1995; 360: 246-56.

367) Grill HJ, Norgren R. Chronically decerebrate rats demonstrate satiation but not bait shyness. Science 1978; 201: 267-9. 
368) Seeley RJ, Grill HJ, Kaplan JM. Neurological dissociation of gastrointestinal and metabolic contributions to meal size control. Behavioral neuroscience 1994; 108: 347-52.

369) Berthoud HR. First step to losing fat: central melanocortin signaling and sympathetic lipolytic drive. American journal of physiology. Regulatory, integrative and comparative physiology 2005; 289: R1236-7.

370) Blevins JE, Morton GJ, Williams DL, Caldwell DW, Bastian LS, Wisse BE, Schwartz MW, Baskin DG. Forebrain melanocortin signaling enhances the hindbrain satiety response to CCK-8. American journal of physiology. Regulatory, integrative and comparative physiology 2009; 296: R476-84.

371) Wan S, Browning KN, Coleman FH, Sutton G, Zheng H, Butler A, Berthoud HR, Travagli RA. Presynaptic melanocortin-4 receptors on vagal afferent fibers modulate the excitability of rat nucleus tractus solitarius neurons. The Journal of neuroscience : the official journal of the Society for Neuroscience 2008; 28: 4957-66.

372) Hayes MR, Skibicka KP, Leichner TM, Guarnieri DJ, DiLeone RJ, Bence KK, Grill HJ. Endogenous leptin signaling in the caudal nucleus tractus solitarius and area postrema is required for energy balance regulation. Cell metabolism 2010; $11: 77-83$.

373) Williams DL, Grill HJ, Cummings DE, Kaplan JM. Overfeeding-induced weight gain suppresses plasma ghrelin levels in rats. Journal of endocrinological investigation 2006; 29: 863-8.

374) Grill HJ, Donahey JC, King L, Kaplan JM. Contribution of caudal brainstem to d-fenfluramine anorexia. Psychopharmacology 1997; 130: 375-81.

375) Kaplan JM, Song S, Grill HJ. Serotonin receptors in the caudal brainstem are necessary and sufficient for the anorectic effect of peripherally administered mCPP. Psychopharmacology 1998; 137: 43-9.

376) Emond M, Schwartz GJ, Ladenheim EE, Moran TH. Central leptin modulates behavioral and neural responsivity to CCK. The American journal of physiology 1999; 276: R1545-9.

377) Emond M, Ladenheim EE, Schwartz GJ, Moran TH. Leptin amplifies the feeding inhibition and neural activation arising from a gastric nutrient preload. Physiology \& behavior 2001; 72: 123-8.

378) Morton GJ, Blevins JE, Williams DL, Niswender KD, Gelling RW, Rhodes CJ, Baskin DG, Schwartz MW. Leptin action in the forebrain regulates the 
hindbrain response to satiety signals. The Journal of clinical investigation 2005; 115: 703-10.

379) Sawchenko PE. Evidence for differential regulation of corticotropin-releasing factor and vasopressin immunoreactivities in parvocellular neurosecretory and autonomic-related projections of the paraventricular nucleus. Brain research 1987; 437: 253-63.

380) Sawchenko PE, Swanson LW. Immunohistochemical identification of neurons in the paraventricular nucleus of the hypothalamus that project to the medulla or to the spinal cord in the rat. J Comp Neurol 1982; 205: 260-72.

381) Peters JH, McDougall SJ, Kellett DO, Jordan D, Llewellyn-Smith IJ, Andresen MC. Oxytocin enhances cranial visceral afferent synaptic transmission to the solitary tract nucleus. The Journal of neuroscience : the official journal of the Society for Neuroscience 2008; 28: 11731-40.

382) Kirchgessner AL, Sclafani A, Nilaver G. Histochemical identification of a PVNhindbrain feeding pathway. Physiology \& behavior 1988; 42: 529-43.

383) Baskin DG, Kim F, Gelling RW, Russell BJ, Schwartz MW, Morton GJ, Simhan HN, Moralejo DH, Blevins JE. A new oxytocin-saporin cytotoxin for lesioning oxytocin-receptive neurons in the rat hindbrain. Endocrinology 2010; 151: 4207-13.

384) Blevins JE, Eakin TJ, Murphy JA, Schwartz MW, Baskin DG. Oxytocin innervation of caudal brainstem nuclei activated by cholecystokinin. Brain research 2003; 993: 30-41.

385) Tung YC, Ma M, Piper S, Coll A, O'Rahilly S, Yeo GS. Novel leptin-regulated genes revealed by transcriptional profiling of the hypothalamic paraventricular nucleus. The Journal of neuroscience : the official journal of the Society for Neuroscience 2008; 28: 12419-26.

386) Liu H, Kishi T, Roseberry AG, Cai X, Lee CE, Montez JM, Friedman JM, Elmquist JK. Transgenic mice expressing green fluorescent protein under the control of the melanocortin-4 receptor promoter. The Journal of neuroscience : the official journal of the Society for Neuroscience 2003; 23: 7143-54.

387) Yosten GL, Samson WK. The anorexigenic and hypertensive effects of nesfatin-1 are reversed by pretreatment with an oxytocin receptor antagonist. American journal of physiology. Regulatory, integrative and comparative physiology 2010; 298: R1642-7. 


\section{Figure captions}

Figure 1. Changes in Food intake (top) and body weight (bottom) during and after insulin injections. Filled circles are injected animals; open circles are the control animals. Shaded bar indicates injection period. * different from controls.

Figure 2. Diagram of proposed meal size controls. 